\title{
Buku Ajar \\ DIGITAL MARKETING
}

\author{
Penulis: \\ DEWI KOMALA SARI, SE., MM \\ ALSHAF PEBRIANGGARA, SE., MM \\ MAS OETARJO, SE., MM, BKP
}

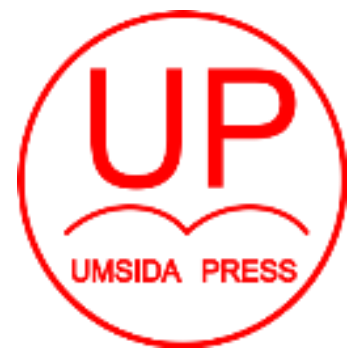

Diterbitkan oleh UMSIDA PRESS

Jl. Mojopahit 666 B Sidoarjo

ISBN: 978-623-6081-38-9

Copyright@2021. Authors

All rights reserved 


\section{Buku Ajar}

\section{DIGITAL MARKETING}

Penulis :

Dewi Komala Sari, SE., MM

Alshaf Pebrianggara, SE., MM

Mas Oetarjo, SE., MM, BKP

\section{ISBN :}

978-623-6081-38-9

\section{Editor :}

M. Tanzil Multazam

Mahardika Darmawan K.W

\section{Copy Editor :}

Wiwit Wahyu Wijayanti

\section{Design Sampul dan Tata Letak :}

Mochamad Nashrullah Penerbit :

UMSIDA Press Redaksi :

Universitas Muhammadiyah Sidoarjo

Jl. Mojopahit No 666B

Sidoarjo, Jawa TImur

Cetakan pertama, Agustus 2021

(C) Hak cipta dilindungi undang-undang

Dilarang memperbanyak karya tulis ini dengan suatu apapun tanpa ijin tertulis dari penerbit. 


\section{KATA PENGANTAR}

Penulis mengucapkan puji syukur kehadirat Tuhan Yang Maha Esa, dengan kesempatan ini kami dapat menyelesaikan penulisan buku Digital Marketing.

Buku Digital Marketing terdiri atas 14 bab, yang membahas tentang Konsep Dasar Digital Marketing, Perkembangan Internet, Website Dan Aplikasnya, Konsep Bisnis Digital Marketing, Bisnis Online, Fungsi Privacy Bagi Pengguna Dalam Digital Marketing, Kepercayaan Dalam Bisnis Online, Keamanan Bisnis Online, Strategi Penentuan Harga Dalam Digital Marketing, Tool Internet Marketing.

Akhirnya saya berharap semoga buku ini dapat berguna dan memberikan manfaat, besar harapan penulis agar pembaca dapat menjadikan buku Digital Marketing sebagai referensi dalam proses pembelajaran matakuliah Digital Marketing. Saran dan kritik yang membangun kami sangat harapkan untuk perbaikan buku ini kedepannya. Penulis juga mengucapkan terima kasih khususnya kepada:

1. Dr. Hidayatullah, M.Si pemangku pimpinan tertinggi yaitu Rektor Universitas Muhammadiyah Sidoarjo yang telah memberikan dan memfasilitasi dalam penulisan buku ajar ini.

2. LP3iK Universitas Muhammadiyah Sidoarjo yang telah memfasilitasi dan mengkoordinasi dalam penulisan buku ajar ini.

3. Wisnu Panggah Setiyono, SE., M.Si., Ph.D sebagai Dekan Fakultas Bisnis, Hukum dan Ilmu Sosial, Universitas 
Universitas Muhammadiyah Sidoarjo yang telah memberikan dukungan untuk mengikuti penulisan buku ajar ini.

Akhir kata, kritik dan saran sangat diharapkan untuk penyempurnaan buku ajar ini. Harapan kami semoga buku ajar ini dapat digunakan sebagai tambahan informasi dan bermanfaat bagi aktivitas pembelajaran mata kuliah Digital Marketing di Program Studi Manajemen, Fakultas Bisnis, Hukum dan Ilmu Sosial, Universitas Muhammadiyah Sidoarjo.

Penulis 


\section{DAFTAR ISI}

\section{HALAMAN SAMPUL \\ KATA PENGANTAR \\ DAFTAR ISI}

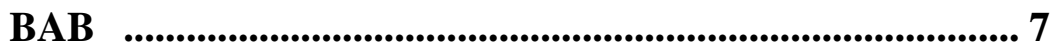

A. Pengertian dan ruang lingkup Digital Marketing .......... 7

B. Mengapa Digital Marketing........................................ 8

C. Peran Digital Marketing terhadap perekonomian........ 13

D. Tren Teknologi Pemasaran Saat Ini ............................. 15

BAB II STRATEGI DIGITAL MARKETING DAN

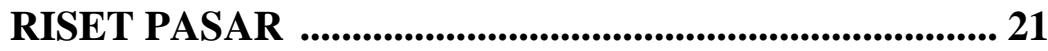

A. Strategi Digital Marketing ......................................... 21

B. Riset Pasar ............................................................... 23

C. Ruang Lingkup Riset Pemasaran.................................. 26

D. Klasifikasi Riset Pemasaran ........................................ 27

BAB III KONTEN STRATEGI MARKETING ............. 30

A. Definisi Content Marketing ......................................... 30

B. Mengapa Bisnis Memerlukan Content Marketing? ..... 30

C. Bentuk Content Marketing ........................................... 33

D. Skill yang Dibutuhkan dalam Content Marketing....... 35

BAB IV DESAIN PENGALAMAN PENGGUNA, PENGEMBANGAN DAN DESAIN WEB ....................... 38

A. Definisi User experience ……………………............ 38

B. Faktor yang Mempengaruhi User Experience ............. 39

C. Model User Experience .............................................. 46

BAB V TEKNIK PENULISAN DIGITAL DAN

PENGELOLAAN HUBUNGAN PELANGGAN ............. 51 

A. Definisi Copywriting ................................................... 51
B. Peran Copywriting Itu Penting Dalam Bisnis .............. 51
C. Model Copywriting.................................................... 52

BAB VI SEARCH ENGINE OPTIMIZATION ............. 55

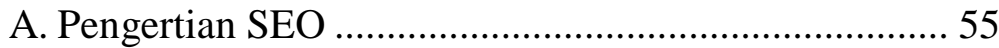

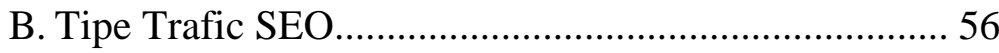

C. Cara Kerja dan Teknik SEO ......................................... 57

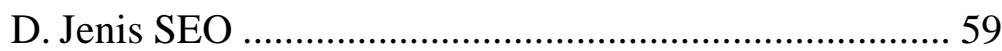

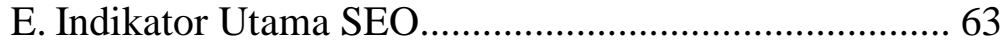

F. Manfaat Dari Adanya SEO ........................................... 66

\section{BAB VII SEARCH ADVERTISING DAN ONLINE}

ADVERTISING ..............................................................68

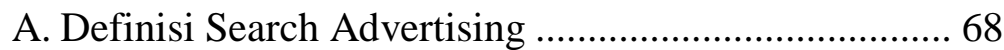

B. Aktivitas Periklanan ..................................................... 69

C. Efisiensi Advertising .................................................... 72

D. Jenis Iklan Pencarian....................................................... 75

E. Iklan Online/Online Advertising ........................................ 76

F. Jenis Online Advertising......................................................... 77

G. Macam-Macam Online Advertising ..................................... 79

KONSEP DASAR DIGITAL MARKETING 


\section{BAB I \\ KONSEP DASAR DIGITAL MARKETING}

\section{A. Pengertian dan ruang lingkup Digital Marketing}

Pemasaran sering dianggap kebanyakan orang sesederhana promosi atau iklan. Tapi sebenarnya pemasaran merupakan konsep kompleks yang digunakan untuk membuat rencana tindakan komprehensif untuk menciptakan kesadaran tentang bisnis; meningkatkan basis pelanggan; meningkatkan penjualan, dan mempromosikan produk dan merk; serta membangun brand. Pemasaran tersebut perlu dilakukan secara efektif, cermat, kreatif dan cerdas, supaya pertumbuhan bisnis optimal.

Internet telah menjadi faktor yang paling mempengaruhi perubahan budaya, ekonomi dan sosial yang terlihat pada abad ke-21 (Henning dkk, 2010). Cara manusia dalam berbicara, berkomunikasi, bertindak, dan mengambil keputusan sudah banyak berubah dengan kehadiran teknologi digital, demikian juga halnya dengan pemasaran. Seiring dengan kemajuan teknologi (perkembangan internet dan World Wide Web serta teknologi digital lainnnya), tren di dunia bisnis juga semakin bervariasi dan berkembang, salah satu tren tersebut berupa pemasaran digital 
(digital marketing). Secara umum digital marketing atau pemasaran digital merupakan teknik pemasaran berbasis internet yang semakin dibutuhkan.

\section{B. Mengapa Digital Marketing}

Digital marketing menjadi salah satu strategi yang paling banyak diterapkan oleh berbagai perusahaan dalam melakukan promosi di era Revolusi Industri 4.0. Ditambah lagi dengan fitur penunjang yang mumpuni akan membuat digital marketing semakin efektif. Lalu digital marketing ini penting bagi kesuksesan

\section{Terhubung ke konsumen dengan mudah}

Mengapa digital marketing itu penting, alasan utamanya adalah untuk memudahkan komunikasi dengan konsumen. Konsumen akan merasa dihargai bila dilayani dengan baik dan cepat oleh perusahaan. Begitu juga jika perusahaan mengeluarkan produk baru, bisa melakukan promosi secara langsung kepada konsumen.

Terlepas apakah hubungan tersebut dibangun melalui, email, platform media sosial hingga melalui nomor telepon yang digunakan konsumen tersebut. Di samping itu, perusahaan juga bisa menerapakan strategi omnichannel yakni memadukan digital marketing dengan cara konvensional. Dengan cara ini akan meningkatkan engagement konsumen hingga 89\% berdasarkan riset yang dirilis oleh Invesp. 
Buku Ajar Digital Marketing | 9 


\section{Mampu melacak perilaku konsumen}

Digital marketing juga mampu melacak perilaku konsumen, dari sinilah Anda bisa melihat apa yang sedang trending dan paling dibutuhkan oleh konsumen. Untuk melacak bagaimana perilaku konsumen tersebut, perusahaan bisa menggunakan fitur kecerdasan buatan atau Artificial Intelligence (AI). Keberadaan AI ini memang memiliki kelebihan dalam mengolah data konsumen dalam jumlah besar sehingga bisa menciptakan tren pasar baru.

Bahkan data dari Forrester's Global State of Artificial Intelligence Online Survey menyebutkan jika 57\% perusahaan menggunakan AI untuk meningkatkan pelayanan pada konsumen mereka. Dengan demikian, keberadaan AI dapat meningkatkan penjualan dari produk yang ditawarkan perusahaan hingga sekitar $44 \%$.

\section{Memperluas pangsa pasar}

Tujuan utama dari marketing adalah untuk memperluas pangsa pasar dan pada akhirnya menyasar calon konsumen baru. Apabila konsumen ini tertarik dengan produk yang ditawarkan, maka akan laku keras dan akan menambah pendapatan bagi perusahaan. Strategi marketing cara lama atau konvensional bisa saja menjangkau pangsa pasar tertentu. Akan lebih baik lagi bila Anda menggunakan digital marketing, baik itu melalui website perusahaan, media sosial hingga melalui email marketing. 
Jangkauannya pun sangat luas. Anda tidak hanya menjangkau di daerah-daerah sekitar atau dalam negeri saja, bahkan dapat memperluas pangsa pasar di seluruh dunia. Namun perlu diingat, dalam memperluas pangsa pasar melalui digital marketing sebaiknya Anda perlu membuat konten menarik dan tidak membosankan calon konsumen.

Menekan biaya marketing konvensional Riset yang dilakukan oleh eMarketer pada tahun 2016 lalu menunjukkan bahwa biaya digital marketing melampaui jumlah iklan yang ada di televisi. Memang, sebelumnya televisi dikenal sebagai media paling efektif untuk melakukan promosi produk dari sebuah perusahaan. Di samping itu, ada pula media lainnya seperti koran, majalah hingga reklame yang juga tidak kalah efektifnya.

Akan tetapi jika dilihat kembali, jumlah pengeluaran untuk marketing melalui media-media konvensional tersebut cukup mahal. Anda harus membayar pajak yang tentu tidak sedikit dan perizinan yang cukup rumit. Berbeda halnya bila menggunakan digital marketing yang dinilai tidak mengeluarkan biaya besar namun hasilnya sangat efektif. Contohnya saja Anda bisa menggandeng agency untuk memasarkan produk perusahaan di ranah digital. 


\section{Semakin Kompetitif di Era Digital}

Menggunakan digital marketing juga memberikan nilai tambah bagi perusahaan Anda. Salah satunya adalah perusahaan akan dipandang semakin kompetitif dalam menghadapi era digital seperti saat ini. Dengan begitu citra perusahaan pun semakin meningkat, bahkan bisa saja menjadi kunci keberhasilan dalam melakukan kerjasama-kerjasama dengan perusahaan atau mitra bisnis Anda di masa mendatang. Terlebih lagi bila Anda menggunakan tools CRM yang mampu meningkatkan penjualan dan pemasaran seperti $\mathrm{ZOHO}$ yang salah satunya bisa kamu dapatkan dari layanan ISEKA Service. Tentu, hal tersebut akan mendatangkan keuntungan yang tidak sedikit dan mampu meningkatkan pemasukan bagi perusahaan nantinya.

Untuk melakukan digital marketing agar makin efektif dan optimal, Anda juga perlu memiliki jaringan internet dan IT terbaik. Oleh karena itu, Anda bisa menggandeng perusahaan yang memberikan solusi IT terbaik dengan reputasi terpercaya dalam menunjang digital marketing tersebut. Dapatkan informasi lebih lanjut, Anda dapat mengaksesnya di http://iseka.services/ . Semoga bermanfaat dan menjadi bahan pertimbangan Anda sebelum melakukan digital marketing. 


\section{Peran Digital Marketing terhadap}

perekonomian

Dunia digital diprediksi akan menjadi poin krusial bagi seluruh aktivitas manusia, termasuk aktivitas bisnis. Beberapa indikator yang bisa digunakan saat ini antara lain naiknya pengeluaran iklan digital, pertumbuhan kepemilikan smartphone yang menyediakan kemudahan akses internet, perbaikan infrastruktur telekomunikasi dalam rangka peningkatan kualitas akses data, serta diluncur- kannya layanan 4G. Menurut data Facebook, $74 \%$ pengguna internet di Indonesia menggunakan perangkat mobile (Utomo, 2016).

Pesatnya perkembangan teknologi, dunia digital dan internet tentu juga berimbas pada dunia pemasaran. Tren pemasaran di dunia beralih dari yang semula konvensional (offline) menjadi digital (online). Strategi digital marketing ini lebih prospektif karena memungkinkan para calon pelanggan potensial untuk memperoleh segala macam informasi mengenai produk dan bertransaksi melalui internet. Digital marketing adalah kegiatan promosi dan pencarian pasar melalui media digital secara online dengan memanfaatkan berbagai sarana misalnya jejaring sosial. Dunia maya kini tak lagi hanya mampu menghubungkan orang dengan perangkat, namun juga orang dengan orang lain di seluruh penjuru dunia. Digital marketing yang biasanya terdiri dari pemasaran interaktif dan terpadu memudahkan interaksi antara produsen, perantara 
pasar, dan calon konsumen. Di satu sisi, digital marketing memudahkan pebisnis memantau dan menyediakan segala kebutuhan dan keinginan calon konsumen, di sisi lain calon konsumen juga bisa mencari dan mendapatkan informasi produk hanya dengan cara menjelajah dunia maya sehingga mempermudah proses pencariannya. Pembeli kini semakin mandiri dalam membuat keputusan pembelian berdasarkan hasil pencariannya. Digital marketing dapat menjangkau seluruh masyarakat di manapun mereka berada tanpa ada lagi batasan geografis ataupun waktu.

Gambar di atas menjelaskan bahwa terhitung sampai Januari 2019, sebanyak 93\% pengguna internet di Indonesia melakukan pencarian barang atau jasa secara online, $90 \%$ pengguna mengunjungi toko online dengan berbagai perangkat, $86 \%$ pengguna melakukan transaksi online dari berbagai perangkat (laptop dan mobile), $37 \%$ pengguna melakukan transaksi melalui PC atau laptop, dan $76 \%$ pengguna melakukan

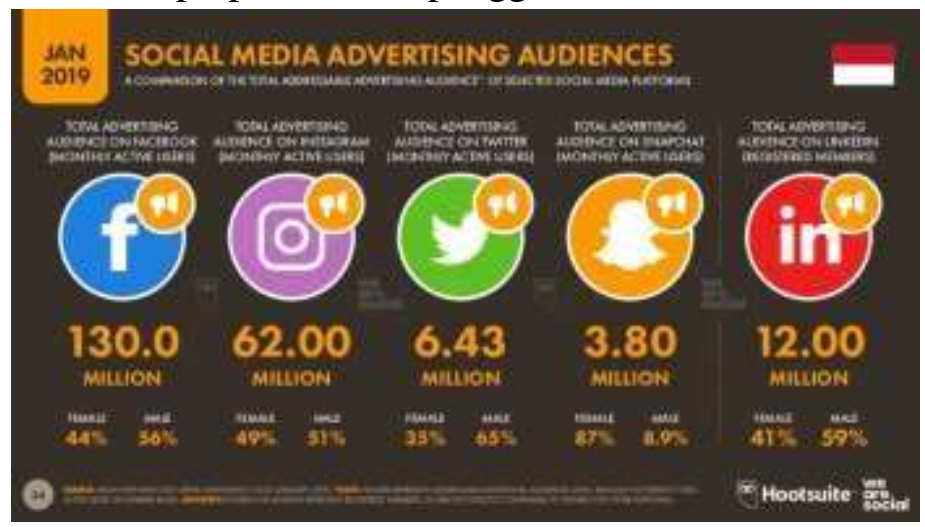


transaksi online melalui perangkat smartphone. Dari penjelasan diatas menyiratkan bahwa potensi belanja online sudah cukup berkembang di Indonesia yang harus diimbangi dengan pemasaran secara digital pula oleh pelaku usaha. Pengguna dalam melakukan pemasaran secara online yaitu dengan media sosia atau jejaring sosial. Jejaring sosial yang tersedia terkadang memiliki karakteristik yang berbeda. Ada yang sifatnya untuk menjalin pertemanan seperti Facebook, Instagram, Line, ada pula yang khusus untuk mencari dan membangun relasi seperti yang ditawarkan Linkedin. Tersedia pula media yang lebih pribadi seperti e-mail (electronic mail). Dari berbagai macam platform yang disampaikan di atas, pelaku usaha juga dapat memanfaatkan media situs pribadi.

\section{Tren Teknologi Pemasaran Saat Ini}

Digital Marketing di era sekarang semakin berkembang. orang - orang pun mulai mempelajari dan beralih dari konvensional ke digital. apalagi di era new normal ini semua dipaksa melakukan apapun serba online \& digital, maka dari itu kita mesti memahami apa yang menjadi trend digital marketing setiap tahunnya supaya tidak termakan jaman dan tetap update perkembangan terbaru dari digital marketing.

Setiap tahunnya trend marketing selalu mengalami perubahan, khusus di tahun 2020 ini sepertinya trend digital marketing yang mengalami perkembangan yang sangat pesat. Sebagai seorang 
pemilik bisnis anda tentu perlu memahami perkembangan atau trend marketing agar bisnis yang di jalankan bisa terus bertahan dan berkembang.

Mengikuti perkembangan zaman, perubahan trend marketing semakin signifikan ketika berbagai teknologi seperti Artificial Intelligence (AI) semakin sering di aplikasikan pada strategi pemasaran. Jika anda perhatikan penggunaan AI dalam memasarkan produk atau brand semakin meningkat. Lalu di tahun 2020 ini apa saja trend digital marketing yang mungkin akan banyak di gunakan oleh para marketer.

1. Artificial Intelligence (AI)

Sepertinya penggunaan AI masih menjadi primadona bagi kebanyakan marketer saat ini. Bahkan menurut lembaga riset Gartner, mereka sudah memperkirakan bahwa di tahun 2020 teknologi AI akan semakin sering di gunakan terutama pada produk software. Saat ini saja setidaknya para marketer sudah memanfaatkan AU untuk menyesuaikan iklan yang akan di tampilkan pada target pasar secara online.

Selain itu AI juga sering di gunakan untuk menganalisis perilaku dan kebiasaan para konsumen sehingga dapat menemukan pola terbaik. Tak sampai di situ saja, AI juga dapat di gunakan untuk mengumpulkan data pada berbagai platform media sosial serta unggahan blog. Nantinya data tersebut dapat di gunakan untuk membantu para pemilik 
bisnis mengetahui bagaimana para konsumen dapat menemukan produk dan layanan mereka.

2. Personalisasi Iklan

Masih berkaitan dengan teknologi AI, personalisasi iklan saat ini juga mulai menjadi trend marketing yang dapat anda terapkan melalui penggunaan hasil analisis pelanggan. Selain dari website, anda juga dapat melakukan analisis dari data yang dapat anda peroleh dari hasil penayangan video iklan atau konten yang anda bagikan di berbagai platform media sosial.

Semakin bertambahnya marketer yang menggunakan teknologi AI membuat para pelanggan membutuhkan pendekatan yang lebih manusiawi. Bahkan berdasarkan survei yang di lakukan oleh Epsilon mengatakan bahwa kebanyakan pengguna internet dengan rentang usia 18-64 tahun mreka mengaku jika pendekatan secara personal jauh lebih menarik bagi mereka.

3. Influencer

Influencer adalah orang yang mampu untuk menyampaikan pesan yang ditujukan oleh brand kepada para pengikutnya. Influencer yang di pilih biasanya memiliki niche yang sama dengan brand yang ingin memasang iklan. Contohnya seperti jika anda memiliki bisnis yang bergerak di bidang fashion maka anda dapat memilih influencer yang sering membahas seputar tutorial beauty and fashion. 
Alasan mengapa anda perlu menggunakan influencer untuk meningkatkan brand dan target pasar anda adalah karena influencer menjadi trend marketing yang sedang mengalami peningkatan. Selain itu pendekatan yang anda lakukan juga terasa lebih personal ke target sasaran. Karena anda memang menawarkan ke pelanggan yang potensial.

4. Konten Marketing

Berbagai website saat ini berlomba-lomba untuk meningkatkan konten yang di buat agar bisa mendapatkan posisi teratas di hasil pencarian Google. Hingga di tahun 2020 ini, ternyata konten yang mendominasi SEO masih menjadi trend marketing yang masih banyak di gunakan. Jangan sampai ketinggalan anda juga harus menerapkan strategi ini pada bisnis anda.

Konten marketing sangat berguna untuk meningkatkan awareness bagi khalayak pengguna internet. Selai itu konten marketing yang baik juga akan membantu anda dalam meningkatkan brand serta bisnis yang anda jalankan. Selain konten, website yang berkualitas juga sangat di butuhkan untuk mendongkrak konten supaya bisa mendapatkan posisi terbaik di mesin pencari.

\section{Stories di Media Sosial}

Anda pasti sudah tidak asing ;agi dengan fitur Stories yang ada di berbagai media sosial. Pada awalnya fitur ini hanya tersedia untuk aplikasi Snapchat, kemudian Instagram juga meluncurkan 
fitur "Instagram Stories" dan di ikuti juga oleh media sosial lain seperti Facebook, Skype dan YouTube.Anda dapat memanfaatkan fitur ini untuk memberikan sentuhan Fear of Missing Out kepada target sasaran anda.

Pasalnya konten yang di unggah pada stories hanya dapat bertahan selama 24 jam atau sementara. Sehingga para pengikut media sosial bisnis anda harus cepat untuk mendapatkan informasi yang mereka butuhkan mengenai bisnis anda. Fitur semacam ini dapat anda gunakan untuk meningkatkan awareness, engagement serta traffic website dengan tanpa mengeluarkan biaya sedikitpun.

Demikianlah pembahasan mengenai trend digital marketing di tahun 2020. Meskipun trend marketing selalu berubah setiap tahunnya, bukan berarti trend marketing di tahun sebelumnya sudah tidak efektif lagi. Walau bagaimana pun anda harus tetap menyesuaikan strategi marketing yang di gunakan dengan bisnis yang sedang anda jalankan.

6. Digital Advertising (Periklanan Digital)

Semakin berkembangnya jaman, media sosial, website, platform. digital advertising, periklanan digital / periklanan online akan menjadi pilihan terbaik bagi para pebisnis / pengusaha dalam memasarkan produk ataupun brand mereka. Dikarenakan digital advertising memiliki kemampuan penargetan audience yang spesifik dan 
relevan, baik dari sisi interest, demografi, umur sampai lokasi. Bukan hanya itu digital advertising sekarang ini memiliki kemampuan dalam mengukur hasil iklan secara transparan, salah satunya seperti google ads, facebook \& instagram ads, youtube ads dan masih banyak lagi. Oleh karena itu permintaan periklanan digital ini menjadi kian marak karena hasil yang sudah banyak dirasakan oleh para pebisnis.

7. Video Marketing

Seiring berkembangnya teknologi mulai dari suara, gambar dan sekarang video. video akan membuat orang lebih engage dibanding media lainnya karena unsur dari video berisi visual, audio, text dimana mencakupi semua unsur. orang-orang lebih senang melihat video karena memanjakan mata dan menarik. tik tok sekarang menjadi populer dengan isi video 2 yang ringan dan menjadi hiburan bagi penontonnya. 


\section{BAB II STRATEGI DIGITAL MARKETING DAN RISET PASAR}

\section{A. Strategi Digital Marketing}

Ada begitu banyak strategi digital marketing dan kadang-kadang bisa sangat melelahkan ketika Anda mencoba memutuskan mana yang akan diprioritaskan. Pemasar yang mencari strategi pemasaran digital utama harus memiliki pemahaman yang jelas tentang bisnis, produk, dan demografi mereka sebelum memilih strategi pemasaran digital yang akan efektif untuk kebutuhan mereka.

Strategi digital marketing adalah strategi yang digunakan para pelaku bisnis dalam memaksimalkan potensi aktivitas digital marketing yang sedang dilaksanakan. Setiap pelaku bisnis atau perusahaan memiliki strategi digital marketing yang berbeda-beda, disesuaikan pada kebutuhan dan tujuan yang ingin dicapai.

Secara sederhana, berikut ini langkah strategi digital marketing bagi pemula:

1. Digital Assets Development,

Langkah pertama adalah menyiapkan identitas digital sebuah bisnis. Aktivitas yang dilakukan antara lain membangun website dan menyiapkan akun social media (contoh: Facebook, Instagram, YouTube, dll) 
2. Meningkatkan kunjungan website,

Dengan melakukan beberapa cara seperti optimasi SEO (Search Engine Optimization), pemasangan iklan CPC melalui Google Adsense, dll.

3. Optimasi akun social media,

Mengupayakan peningkatan interaksi dengan para pengguna social media dengan cara menyiapkan dan mempublikasikan konten yang menarik. Selain itu optimalisasi dengan cara beriklan di social media juga patut untuk dipertimbangkan.

4. Email Marketing activities.

Email sebagai alat komunikasi digital yang dikenal kuno ini nyatanya masih memiliki potensi peningkatan sales sebuah bisnis. Tidak dapat dipungkiri bahwa semua pengguna smartphone diwajibkan untuk memiliki akun email untuk bisa memanfaatkan fitur smartphone secara maksimal. Kondisi ini merupakan potensi yang sangat bagus jika dapat dimanfaatkan denggan baik.

5. Broadcast message

Bagian dari digital marketing yang masih bisa kita jumpai. Tak jarang kita masih mendapatkan broadcast message seperti pesan singkat (SMS), Whatsapp, hingga Social Media Direct Message. Meskipun rentan mengalami pemblokiran akun, nyatanya broadcast message masih memiliki conversion rate yang cukup baik. 
Selain kelima strategi di atas, ada banyak lagi strategi digital marketing yang masih sangat potensial untuk dilakukan. Mengingat strategi digital marketing merupakan bagian dari pekerjaan tim kreatif yang cakupannya sangat luas demi meningkatkan interaksi bisnis dengan calon customer.

\section{B. Riset Pasar}

Riset pasar adalah teknik yang biasa digunakan oleh para pebisnis untuk mengumpulkan dan menganalisis data atau informasi yang akan berguna bagi bisnisnya. Riset pasar penting untuk dilakukan sebelum menjalankan bisnis dan memasarkan produk secara meluas. Dengan melakukan riset pasar terlebih dahulu, kamu sebagai pebisnis akan mengetahui apa produk atau layanan yang benar-benar dibutuhkan oleh mereka.

Dulu jika ingin melakukan riset pasar maka artinya kamu harus menyiapkan banyak hal dan waktu untuk bertemu langsung dengan berbagai sumber untuk ditanyai. Seringnya riset pasar yang seperti ini membutuhkan biaya besar.

Dengan kemajuan teknologi saat ini riset pasar sudah bisa dilakukan secara online melalui mesin pencari di internet, yang jauh lebih mudah, praktis, dan irit. Dengan cara ini, kamu bisa mencari tahu permintaan atau selera konsumen untuk mendapatkan informasi mengenai penilaian tentang produk yang dijual. 
Berikut beberapa langkah yang bisa kamu coba dalam melakukan riset pasar secara online :

1. Melakukan pencarian dengan kata kunci di internet

Pencarian dengan menggunakan kata kunci dapat dilakukan di mesin pencari internet atau di beberapa aplikasi jejaring sosial. Mesin pencari utama yang umum dipakai adalah Google atau Bing, sedangkan aplikasi jejaring sosial yang bisa kamu jadikan referensi adalah Facebook, Twitter, juga Instagram. Bukalah mesin pencari lalu ketikkan kata kunci yang terkait dengan produk yang kamu cari. Misalnya, kalau kamu ingin melakukan riset pasar untuk produk makanan sehat, maka kamu bisa memasukkan kata kunci seperti 'makanan sehat favorit' atau 'jenis makanan sehat yang paling digemari'.

Opsi menggunakan kata kunci ini bisa juga digabung dengan pencarian di jejaring sosial, karena biasanya pembicaraan atau diskusi yang ada di jejaring sosial akan lebih spesifik. Misalnya kalau kamu mengetikkan kata kunci seperti yang di atas tadi di kolom pencarian Twitter atau Facebook, maka yang muncul adalah komentarkomentar dari para konsumen berkaitan dengan produk tersebut. Hal ini jauh lebih praktis dan efisien untuk memahami apa yang sebenarnya diinginkan oleh para konsumen.

2. Mengadakan survei 
Survei dilakukan dengan konsep mengajukan beberapa pertanyaan sederhana tentang produk atau jasa yang menjadi bahan riset kamu. Sekarang, survei secara online dianggap lebih efektif dibandingkan survei dengan cara offline atau harus bertemu langsung dengan para respondennya. Dengan melakukan survei secara online kamu bisa mendapatkan respon lebih cepat, minim biaya, dan mudah untuk dilakukan.

Survei online ini bisa kamu lakukan menggunakan akun jejaring sosial milik pribadi, akun media sosial milik perusahaan, juga bisa dari web perusahaan. Masukkan beberapa pertanyaan untuk produk atau jasa yang sedang kamu riset untuk dijawab oleh para pengunjung web atau dari lingkar pertemanan media sosial kamu. Yang harus dipastikan adalah penyebarluasan surveinya. Kamu harus bisa memastikan bahwa pertanyaanpertanyaan yang kamu ajukan sudah tepat sasaran. Contohnya, tidak mungkin kan kalau kamu ingin mensurvei tentang produk laundri tapi yang kamu beri pertanyaan adalah remaja rentang usia 13-17 tahun?

Dari dua cara di atas, kamu akan bisa mengetahui bagaimana selera konsumen yang ada di pasaran. Korelasinya, jika kamu mengetahui selera konsumen maka otomatis kamu dapat mengidentifikasi peluang untuk bisnismu dan menentukan cara agar bisnis tersebut terus maju. 


\section{Ruang Lingkup Riset Pemasaran}

Riset Pemasaran merupakan suatu kegiatan yang sistematik dan mempunyai tujuan dalam hal pengindentifikasian masalah, peluang,

Pengumpulan data, pengolahan dan penganalisaan data, penyebaran informasi yang bermanfaat untuk membantu manajemen dalam rangka pengambilan keputusan identifikasi dan solusi yang efektif-efisien di bidang pemasaran perusahaan. Menurut Maholtra dalam American Marketing Association (AMA) mengatakan bahwa riset pemasaran adalah identifikasi, pengumpulan, analisis, dan penyebaran (pembagian) informasi yang sistematis dan objektif untuk meningkatkan pengambilan keputusan yang berhubungan dengan identifikasi dan solusi masalahmasalah dan kesempatan-kesempatan dalam pemasaran. Dari pendapat diatas, maka dapat disimpulkan bahwa riset pemasaran adalah proses identifikasi, pengumpulan, analisis, dan penyebaran informasi tentang masalah-masalah dan kesempatankesempatan pasar secara sistematis, dimana hasil yang diperoleh dipakai sebagai bahan pertimbangan untuk membuat keputusan-keputusan untuk mengevaluasi, memonitor, dan mengoptimalkan performa pemasaran. 


\section{Klasifikasi Riset Pemasaran}

Menurut Maholtra, 1996 dalam Bilson Simamora, 2004:51 dikatakan bahwa riset pemasaran dibagi ke dalam dua kategori yaitu riset identifikasi masalah (problem identification research) dan riset mengatasi masalah (problem solving research). Secara lebih rinci keduanya dapat diperbandingkan dalam tabel sebagai

\begin{tabular}{|c|c|}
\hline $\begin{array}{l}\text { Riset Identifikasi Masalah } \\
\text { (problem identification neseareh) }\end{array}$ & $\begin{array}{l}\text { Riset Mengatasi Masalah } \\
\text { (problem sohing nowench) }\end{array}$ \\
\hline - Market potensial research & - Segmentation reseirch \\
\hline - Market share research & m Product research \\
\hline - lmage research & - Pricing research \\
\hline - Forocasting research & - Promotion reseurch \\
\hline - Business trend rssearch & - Distribution rescarch \\
\hline
\end{tabular}

berikut:

Jika melihat beberapa contoh penelitian yang berkategori mengidentifikasi masalah seperti disebut di atas, maka nampak bahwa pada dasarnya penelitian identifikasi masalah lebih bersifat preventif. Suatu perusahaan yang dihadapkan pada situasi pasar yang memiliki tingkat kompetisi ketat, selalu dituntut untuk memperbaharui berbagai informasi dan fenomena pasar yang fluktuatif dan massif. Seberapa tingkat fluktuasi dan massifitas pergerakan arus barang dan jasa yang ada di pasar, akan sangat berpengaruh terhadap potensi pasar (market potensial), pangsa pasar (market share), maupun persepsi (produk image) konsumen atas barang dan jasa yang dihasilkan. Selain itu, penelitian identifikasi masalah juga bermaksud memperkirakan (forecast) terhadap kecenderungan (naik-turunnya) 
permintaan (demand) dan penawaran (supply) suatu produk di pasar. Dengan melakukan serangkaian penelitian yang cermat, teliti, dan terukur, maka akan diperoleh data dan berbagai informasi penting yang dapat digunakan oleh pengambil kebijakan (policy maker) dalam menentukan taktik dan strategi bisnis yang akan diterapkan. Kemudian jenis penelitian yang lain dalam lingkup pemasaran adalah penelitian bagaimana cara mengatasi suatu masalah yang muncul dalam suatu perusahaan. Dalam konteks perusahaan yang baru akan tumbuh dan berkembang, penelitian bagaimana cara mengatasi masalah yang mungkin bisa timbul di kemudian hari, serta pilihan mana yang akan diambil sangat tergantung pada ketersediaan data hasil penelitian yang dilakukan. Sejauhmana produk yang akan dihasilkan dan siap dilempar ke pasar sehingga direspon oleh khalayak ataukah tidak sangat ditentukan oleh ketepatan dalam melakukan segmentasi pasar (market segmentation) sebelumnya. Penelitian segmentasi bertujuan untuk memilih sasaran dan menganalisis atribut-atribut seperti demografi, karakter produk, dan profil gaya hidup. Penelitian seputar produk seringkali difokuskan pada bagaimana menentukan desain, kemasan, modifikasi, dan penempatannya di suatu tempat. Kemudian penelitian tentang harga berorientasikan pada cara pandang pentingnya kebijakan menentukan harga suatu produk yang akan dijual. Penentuan harga akan berimplikasi pada penerimaan atau penolakan pasar, sehingga 
kegiatan penelitian tentang respon pasar terhadap penentuan harga, perubahan (penurunan atau kenaikan) sangat membantu pihak perusahaan dalam melakukan langkah-langkah selanjutnya. Sedangkan penelitian yang tidak kalah pentingnya dalam mengatasi/memecahkan masalah pemasaran adalah bagaimana menentukan promosi dan distribusi produk. Penelitian tentang aspek promosi berfokus pada penentuan anggaran, efektifitas, dan efisiensi anggaran promosi tersebut dijalankan. Apa efek dari promosi terhadap volume penjualan, jenis bauran promosi yang paling tepat dan efektif dalam mendongkrak volume penjualan?. Menentukan model saluran distribusi yang tepat dengan kombinasi biaya dan jarak serta biaya dan waktu tempuh, sangat membutuhkan data dan informasi yang diperoleh melalui serangkaian kegiatan penelitian. Dalam konteks perusahaan yang sudah matang (mature), penelitian mengatasi masalah adalah sebagai upaya dalam mempertahankan dan meningkatkan kepuasan pelanggan (costumer satisfaction) setianya disatu pihak, serta bagaimana tetap bisa menjaga persaingan terhadap perusahaan lain sejenis di pihak yang lain. Disamping itu, kegiatan penelitian pemasaran yang dilakukan akibat dari tuntutan perusahaan dalam merespon, mengantisipasi, mencari solusi, dan kemudian menerapkannya dalam strategi bisnis adalah wujud dari penelitian mengatasi masalah. 


\section{BAB III KONTEN STRATEGI MARKETING}

\section{A. Definisi Content Marketing}

Menurut Content Marketing Institute, content marketing bisa didefinisikan sebagai sebuah strategi marketing yang fokus dalam membuat dan mendistribusikan konten yang berharga, relevan, dan konsisten untuk menarik dan mendapatkan audience dengan tujuan akhir untuk menghasilkan keuntungan bagi sebuah bisnis.

Saat ini, sudah banyak pemain digital marketing yang menyadari pentingnya content marketing sebagai bagian dari strategi marketing mereka. Menurut sebuah survey oleh Content Marketing Institute, 70\% marketers bisnis B2B mengatakan bahwa mereka membuat lebih banyak konten di tahun 2017 ini jika dibanding tahun 2016.

\section{B. Mengapa Bisnis Memerlukan Content Marketing?}

Pentingnya content marketing telah berkembang secara signifikan. Content marketing adalah salah satu cara paling efektif bagi Anda pebisnis online untuk memasarkan bisnis Anda. Ini dikarenakan pelanggan hanya memilih untuk berinteraksi dengan konten yang menarik minat mereka, berlawanan dengan marketing tradisional. 
Secara statistik, content marketing dapat meningkatkan conversion rate Anda sebesar 6 kali lipat. Menurut sebuah studi oleh Aberdeen Group, ratarata conversion rate sebuah website yang mengaplikasikan content marketing adalah 2,9\%. Sementara website yang tidak melakukan content marketing hanya mendapat rata-rata conversion rate sebesar $0,5 \%$.

Jika Anda masih tidak yakin dengan keefektifan content marketing, masih banyak studi yang dapat membantu menjelaskan mengapa Anda memerlukan content marketing. Demand Metric memiliki beberapa bukti bahwa content marketing adalah strategi marketing yang efektif.

Content marketing dianggap sebagai strategi marketing yang harus dilakukan karena konten berbicara langsung kepada pelanggan Anda. Dengan adanya konten, Anda bisa meningkatkan komunikasi antara merek dan klien, baik dalam hal yang Anda katakan dan seberapa kuat dampaknya terhadap mereka.

Berikut adalah beberapa hal yang dapat terbantu dengan adanya content marketing:

1. Awareness

Audiens mungkin sadar akan adanya produk yang kamu jual, tapi apakah mereka membutuhkan produkmu? Nah, tugas seorang Content Marketer di sini yaitu membangun kesadaran alias awareness bahwa produkmu mereka butuhkan.

2. Riset 
Setelah audiens aware dengan produkmu dan tertarik untuk membelinya, mereka biasanya akan mencari tahu atau riset terlebih dahulu. Bisa dari segi keunggulan produkmu, keunikannya, atau dari kebutuhan mereka sendiri.

3. Consideration

Setelah mereka riset produk, mereka akan berpikir lagi sebelum memutuskan untuk membeli produkmu. Biasanya mereka akan membandingbandingkan dengan merek lain. Misalnya dari segi harga atau kualitas. Mereka juga akan menimbangnimbang mana yang lebih untung untuk membeli produk A dan B.

4. Beli

Di tahap terakhir ini audiens akhirnya memutuskan untuk membeli sebuah produk yang sesuai dengan keinginan dan kebutuhannya.

Nah, dari keempat tahap ini, content marketing sangat penting untuk memengaruhi perilaku pembelian. Pada umumnya pemasaran tradisional seperti advertising hanya akan memengaruhi tahap pertama dan kedua saja. Menciptakan kesadaran masyarakat akan adanya produk lalu membuat mereka mencari tahu.

Namun, dalam content marketing, tujuan utamanya adalah menjadikan siklus pembelian menjadi dua saja, yaitu aware dan buy. Marketer ingin para audiens atau customer langsung aware dengan produk yang dijual 
tanpa harus riset panjang dan berpikir-pikir serta membandingkan dengan produk lain. Dengan konten yang dibuat, diharapkan para audiens langsung ke tahap pembelian tanpa ragu membeli produk tersebut.

Dengan kata lain, strategi marketing ini sangat penting untuk mempercepat proses audiens dalam membeli atau menggunakan sebuah produk dan menumbuhkan rasa ketergantungan pada brand tersebut.

\section{Bentuk Content Marketing}

1. Infografik

Banyak orang haus akan informasi, tapi kadang kesulitan membaca data yang disajikan dalam penelitian atau tulisan panjang. Tren infografik yang saat ini sering digunakan oleh media dapat menjadi salah satu solusinya.

Infografik bisa menyajikan data yang rumit dalam bentuk yang mudah dipahami. Ya, salah satu kelebihan infografik adalah memadukan gambar dan tulisan tapi informasi yang disampaikan tetap to-the-point.

2. Website atau blog

Jika kamu belum punya wadah untuk menciptakan sebuah konten, website atau blog mungkin bisa kamu manfaatkan. Dalam website dan blog kamu bisa membuat artikel yang sesuai dengan target audiensmu. 
Selain membuat artikel yang sesuai dengan audiens, kamu juga harus memerhatikan SEO-nya. SEO tidak bisa dipisahkan dari content marketing. Pasalnya, strategi SEO yang baik tentu akan mengundang banyak traffic ke situs atau blogmu.

Pastikan juga situs atau blogmu enak dilihat dari smartphone. Ini karena mayoritas pengguna internet di Indonesia mengakses konten melalui smartphone.

\section{Podcast}

Tren yang muncul memang harus dimanfaatkan sebaik-baiknya. Contohnya podcast yang saat ini sedang hype di Indonesia. Beberapa pencipta konten atau brand juga memanfaatkan kesempatan ini untuk menciptakan awareness. Topiknya pun juga bisa disesuaikan dengan target audiens yang ingin disasar.

Podcast merupakan salah satu wadah cerdas pengganti radio. Audiens bisa menikmati kontenmu di mana saja dan kapan saja sambil mengerjakan hal-hal lainnya. Jangan lupa, konten podcast harus selalu relevan agar audiens tetap setia dengan produkmu.

\section{Video}

Video masih menjadi wadah yang efektif dalam content marketing, terutama lewat YouTube. Mengapa? Ini karena kemudahan akses YouTube masih diminati oleh masyarakat di Indonesia. Di 
samping itu, konten dalam bentuk video akan lebih mudah dipahami dan dinikmati.

Buatlah video yang bermanfaat bagi para audiens. Jangan sampai video yang kamu buat hanya mengundang klik karena menjual sensasi ataupun kontroversi yang bisa membahayakan citra brand-mu.

5. Buku

Jika kamu menyasar target audiens yang lebih serius, kamu bisa memanfaatkannya dengan mencurahkan ide atau informasi ke dalam sebuah buku. Content Marketer menerbitkan sebuah buku bukan sekadar ingin menambah pundi-pundi keuntungan. Justru buku bisa jadi alat dalam strategi pemasaran produknya, lho!

Tujuan penulisan atau penerbitan buku ini agar para pembaca mengetahui bisnis atau brand apa yang sedang dibangun. Buku jadi salah satu cara meningkatkan kesadaran masyarakat terhadap produk yang dijual. Selain itu, menerbitkan buku bisa dilihat sebagai salah satu pembuktian bahwa brand tersebut patut dipercaya.

\section{Skill yang Dibutuhkan dalam Content Marketing}

Tertarik untuk terjun langsung dalam dunia content marketing? Nah, ada baiknya kamu mengasah kemampuan dan keterampilan yang dibutuhkan 
seorang Content Marketer yang dijabarkan di bawah ini:

1. Komunikasi

Skill dalam berkomunikasi sangat penting untuk pekerjaan di bidang apa pun. Namun, pada content marketing kamu harus bisa mengasah skill komunikasi baik secara lisan dan tulisan (verbal, dan nonverbal).

Mengapa demikian? Dalam pekerjaan ini, kamu akan berhadapan dengan banyak orang. Konten yang dibuat pun harus bisa menyentuh banyak orang.

Tidak hanya menyoal konten dan audiens, kamu juga akan bekerja di dalam tim sehingga komunikasi yang baik harus tetap dibina agar tidak ada kesalahpahaman. Mempelajari cara berkomunikasi bahkan bisa dimulai dari caramu menulis email kepada klien atau rekan kerja, lho!

2. Menulis

Salah satu bentuk konten yang dibuat dalam content marketing adalah tulisan. Baik itu artikel, copy writing, status di media sosial, atau naskah video. Kamu harus bisa beradaptasi untuk menulis dalam bermacam-macam gaya yang sesuai dengan target audiens.

Untuk latihan menulis, kamu harus banyakbanyak membaca dari berbagai sumber dan menelaah mana style yang pas untuk produkmu. Latihan menulis tanpa membaca berbagai sumber 
lain akan membuat skill-mu mandek di situ saja. Carilah inspirasi sebanyak-banyaknya sehingga kamu bisa selalu penuh ide dan karya.

3. Bercerita

Podcast atau video merupakan salah satu bentuk konten yang dapat kamu coba dalam content marketing. Nah, untuk mengajak audiens agar selalu menonton video atau mendengarkan podcast, dibutuhkan keterampilan bercerita yang lihai.

Kalau kamu punya keterampilan dan bakat dalam bidang ini atau ingin mengasahnya, ikuti kelas public speaking atau kelas radio. Kamu juga harus mendengarkan banyak radio, menonton video, atau mendengarkan podcast lain agar mengetahui bagaimana cara menghibur audiens tanpa visual.

4. Peka

Kamu harus selalu peka pada tren yang muncul saat ini. Ikuti perkembangan apa yang saat ini sedang terjadi atau digemari banyak orang sehingga kontenmu tidak terlihat basi.

Kamu juga harus kreatif dalam melihat tren saat ini. Pilih dengan baik tren mana yang bisa kamu manfaatkan untuk meningkatkan awareness pada produkmu dan mana yang tidak perlu. 


\section{BAB IV DESAIN PENGALAMAN PENGGUNA, PENGEMBANGAN DAN DESAIN WEB}

\section{A. Definisi User experience}

Menurut definisi dari ISO 9241-210, User Experience adalah persepsi seseorang dan responnya dari penggunaan sebuah produk, sistem, atau jasa. User Experience (UX) menilai seberapa kepuasan dan kenyamanan seseorang terhadap sebuah produk, sistem, dan jasa. Sebuah prinsip dalam membangun User Experience adalah khalayak mempunyai kekuasaan dalam menentukan tingkat II-6 kepuasan sendiri (Costumer Rule). Seberapa pun bagusnya fitur sebuah produk, sistem, atau jasa, tanpa khalayak yang dituju dapat merasakan kepuasan, kaidah, dan kenyamanan dalam berinteraksi maka tingkat User Experience menjadi rendah.

Perkembangan dunia digital dan mobile menjadikan User Experience menjadi lebih complicateddan multidimensi. Kini seseorang dapat mengakses sebuah situs web dari berbagai piranti (Wiryawan, 2011).

Perancangan User Experience pun mengalami ekspansi, karena pengalaman dalam sebuah piranti akan berbeda dengan piranti lainnya. Mengakses web dari komputer desktop akan berbeda dengan mengakses web yang sama lewat smartphone. Begitu juga media digital yang ditampilan semakin beragam dengan 
hadirnya social media. Namun dalam hal content delivery sebuah brand harus mengeluarkan satu bahasa yang sama di berbagai channel dan media. Untuk itu konsep User Experience perlu dipelajari lebih lanjut agar komunikasi brand tetap solid dan fokus. Untuk mengerti konsep User Experience kita akan meninjau dua model yang dibuat tentang hal ini, yaitu model Jesse James Garett dan David Armano (Wiryawan, 2011).

\section{B. Faktor yang Mempengaruhi User Experience}

User Experience (UX) sangat penting untuk keberhasilan atau kegagalan suatu produk di pasar, tetapi apa yang kita maksud dengan UX? Terlalu sering, UX bingung dengan kegunaan, yang menggambarkan betapa mudahnya sebuah produk digunakan. Meskipun benar bahwa UX sebagai suatu disiplin dimulai dengan kegunaan, UX telah tumbuh untuk mengakomodasi lebih dari sekadar kegunaan, dan memperhatikan semua aspek UX untuk mengantarkan produk-produk yang sukses ke pasar sangat penting (Soegaard, 2002). Ada tujuh faktor yang menggambarkan pengalaman pengguna, menurut Peter Morville, seorang perintis di bidang UX yang telah menulis beberapa buku terlaris dan menasihati banyak perusahaan Fortune 500 di UX. Morville mengatur tujuh faktor ke dalam 'Pengalaman Pengguna Honeycomb', yang menjadi alat yang terkenal untuk memahami desain UX. Mari kita lihat 
masing-masing faktor pada gilirannya dan apa artinya bagi pengalaman

pengguna secara keseluruhan (Soegaard, 2002)

1. Useful

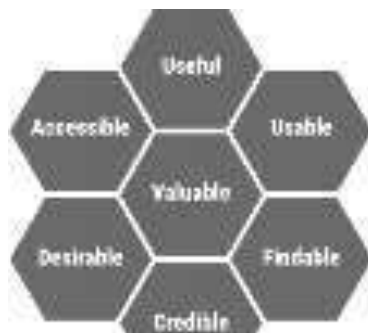

Erodit?

Jika suatu produk tidak berguna bagi seseorang, mengapa Anda ingin membawanya ke pasar? Jika tidak memiliki tujuan, tidak mungkin dapat bersaing untuk mendapatkan perhatian di samping pasar yang penuh dengan produk yang bertujuan dan bermanfaat. Perlu dicatat bahwa 'berguna' ada di mata yang melihatnya, dan hal-hal dapat dianggap 'berguna' jika mereka memberikan manfaat non-praktis seperti kesenangan atau daya tarik estetika. Dengan demikian, permainan komputer atau pahatan dapat dianggap berguna bahkan jika keduanya tidak memungkinkan pengguna untuk mencapai tujuan yang orang lain temukan bermakna. Dalam kasus sebelumnya, seorang remaja mungkin menggunakan permainan untuk melampiaskan kecemasan setelah ujian keras di perguruan tinggi; di yang terakhir, 
pengunjung galeri seni dapat 'menggunakan' patung untuk mendidik dirinya sendiri tentang teknik atau tradisi seniman, mendapatkan kesenangan spiritual pada saat yang sama dari melihatnya.

\section{Usable Usability}

Berkaitan dengan memungkinkan pengguna untuk mencapai tujuan akhir mereka dengan produk secara efektif dan efisien. Sebuah permainan komputer yang membutuhkan tiga set bantalan kontrol tidak mungkin dapat digunakan sebagai orang, untuk saat ini setidaknya, hanya cenderung memiliki dua tangan. Produk dapat berhasil jika tidak dapat digunakan, tetapi cenderung tidak berhasil. Usability yang buruk sering dikaitkan dengan generasi pertama dari sebuah pikirkan produk oleh generasi pertama dari MP3 player, yang sejak itu kehilangan pangsa pasar mereka karena iPod yang lebih bermanfaat. Contoh kasus disini adalah sebuah IPod bukanlah MP3 player pertama, tetapi itu adalah yang pertama setidaknya dalam arti UX dimana benarbenar MP3 player yang dapat digunakan.

3. Findable

Merujuk pada gagasan bahwa produk harus mudah ditemukan, dan dalam hal produk digital dan informasi, konten di dalamnya harus mudah ditemukan juga. Alasannya cukup sederhana: jika Anda tidak dapat menemukan konten yang Anda 
inginkan di situs web, Anda akan berhenti menjelajahinya. Jika Anda mengambil koran dan semua cerita di dalamnya dialokasikan ruang halaman secara acak, daripada diorganisasikan ke dalam bagian-bagian seperti Olahraga, Hiburan, Bisnis, dll., Anda mungkin akan menemukan membaca koran itu pengalaman yang sangat membuat frustrasi. Hal yang sama berlaku untuk memburu piringan hitam di sebuah toko musik antik sementara beberapa mungkin menemukan rifling melalui rak yang diisi secara acak dari berbagai penawaran seniman yang merupakan bagian dari kesenangan dan ritual, banyak dari kita lebih suka memindai melalui bagian-bagian yang diatur secara alfabet, membeli apa yang kita inginkan, keluar dan melanjutkan hari kita. Waktu cenderung berharga bagi kebanyakan manusia, sebagian besar berkat faktor kecil yang disebut 'masa hidup terbatas'. Karena itu, kemampuan menemukan sangat penting bagi pengalaman pengguna banyak produk

\section{Credible}

Pengguna abad ke-20 tidak akan memberi Anda kesempatan kedua untuk mengelabui mereka karena ada banyak alternatif di hampir setiap bidang bagi mereka untuk memilih penyedia produk yang kredibel. Mereka bisa dan akan pergi dalam hitungan detik dan klik kecuali Anda memberi mereka alasan untuk tetap. Kredibilitas 
berkaitan dengan kemampuan pengguna untuk memercayai produk yang telah Anda berikan, tidak hanya karena ia melakukan pekerjaan yang seharusnya dilakukan, tetapi juga bahwa ia akan bertahan untuk jangka waktu yang wajar dan bahwa informasi yang diberikan bersama itu akurat dan sesuai dengan tujuan. Hampir tidak mungkin untuk memberikan pengalaman pengguna jika pengguna berpikir pencipta produk adalah badut bohong dengan niat buruk tetapi sebagai gantinya mereka akan membawa bisnis mereka ke tempat lain, dengan sangat cepat dan dengan ingatan yang sangat jelas tentang kesan yang ditinggalkan oleh pembuatnya. Secara kebetulan, mereka mungkin memberi tahu orang lain, baik secara sepintas atau lebih sengaja, dalam bentuk umpan balik, untuk memperingatkan calon pelanggan, atau 'korban' seperti yang akan mereka lihat.

\section{Desirable}

Skoda dan Porsche sama-sama membuat mobil. Kedua merek, sampai taraf tertentu dari segi useful, usable, findable, accessible, credible dan valuable produk Porsche jauh lebih diinginkan daripada Skoda. Ini bukan untuk mengatakan bahwa Skoda tidak diinginkan tetapi mereka telah menjual banyak mobil. Namun, mengingat pilihan Porsche atau Skoda baru secara gratis, kebanyakan orang akan memilih Porsche. Desirability disampaikan dalam desain melalui branding, 
gambar, identitas, estetika, dan desain emosional. Semakin diinginkan suatu produk, semakin besar kemungkinan pengguna yang memilikinya akan menyombongkan diri dan menciptakan keinginan pada pengguna lain. Ya, kami berbicara tentang iri di sini, sementara kita dapat memberi hormat kepada semangat Skoda yang tak tergoyahkan, paling tidak karena telah membuat langkah yang sangat inovatif dan memanfaatkan sumber daya di balik Tirai Besi dimana kita akan cenderung mendambakan mobil lain di sini, yang meneriakkan 'Lihat aku!' dan ini kekuatan murni dan kemakmuran pada kendaraan roda empat.

6. Accessible

Sayangnya, aksesibilitas sering hilang dalam campuran saat membuat user experience. Aksesibilitas adalah tentang memberikan pengalaman yang dapat diakses oleh pengguna dengan berbagai kemampuan, ini termasuk mereka yang dinonaktifkan dalam beberapa hal seperti pendengaran, penglihatan, gerakan, atau gangguan belajar. Merancang untuk aksesibilitas sering dilihat oleh perusahaan sebagai pemborosan uang. Alasannya adalah kesalahpahaman yang bertahan lama bahwa penyandang disabilitas merupakan bagian kecil dari populasi. Bahkan, menurut data sensus di Amerika Serikat, setidaknya 19\% orang memiliki cacat pada 2010, dan kemungkinan jumlah ini lebih tinggi di negara-negara kurang 
berkembang. Itu satu dari lima orang di antara audiensi untuk produk Anda yang mungkin tidak dapat menggunakannya jika tidak dapat diakses. Penting juga diingat bahwa ketika Anda mendesain aksesibilitas, Anda akan sering menemukan bahwa Anda membuat produk yang lebih mudah digunakan semua orang, bukan hanya mereka yang cacat. Jangan abaikan aksesibilitas dalam pengalaman pengguna, ini bukan hanya tentang menunjukkan kesopanan dan kesopanan tetapi ini juga tentang mengindahkan akal sehat. Akhirnya, desain yang dapat diakses sekarang menjadi kewajiban hukum di banyak yurisdiksi, seperti Uni Eropa. Kegagalan untuk memberikan aksesibilitas dalam desain dapat menghasilkan jaring. Sayangnya, kewajiban ini tidak ditegakkan sesering sebagaimana mestinya tetapi semua sama, jalan kemajuan ada di depan kita.

7. Valuable

Akhirnya, produk harus memberikan nilai maksudnya adalah harus memberikan nilai kepada bisnis yang menciptakannya dan kepada pengguna yang membeli atau menggunakannya. Tanpa nilai, kemungkinan keberhasilan awal suatu produk pada akhirnya akan terkorosi ketika realitas ekonomi alam mulai merusaknya. 


\section{Model User Experience}

Dalam hal ini User Experience (UX) juga mempunyai model untuk peninjauan UX lebih lanjut diantaranya, terdapat dua model konsep yaitu model Jesse James Garett dan David Armano yaitu seperti di bawah ini.

1. Model Jesse James Garett Model

Jesse James Garett dalam bukunya The Elements of User Experience: User-Centered Design for the Web menciptakan sebuah model untuk menjelaskan Elemen dari User Experience (Garrett, 2011).

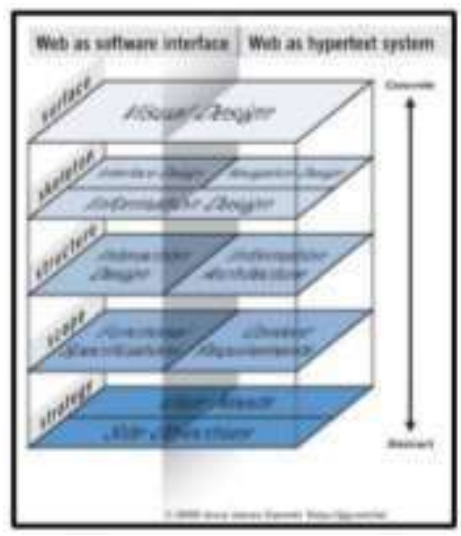

Garrett membagi diagramnya menjadi 5 proses yaitu: bidang strategi, bidang lingkup, bidang struktur, bidang rangka, dan bidang permukaan. Bidang strategi (strategic plane) menjadi platform dari pembentukan cetak biru experience. Disini dirumuskan semua objektif yang ingin dicapai dari proses pembentukan experience, baik dari sisi kebutuhan pengguna maupun produsen 
komunikasi (Garrett, 2011). Tahap bidang lingkup dipertanyakan apa yang menjadi batasan dalam penciptaan pengalaman bagi pengguna. Di bidang ini Garrett membagi menjadi dua sisi yaitu: sisi software interface (konten) dan hypertext system (konteks). Di sisi konteks, sistematika fungsional harus dipertimbangkan. Sedangkan di sisi konten, kebutuhan-kebutuhan informasi harus pula telah dipertimbangkan secara matang.

Batasan Lingkup juga harus datang dari berbagai departmen terkait seperti departemen marketing, sales, supply chain, IT, dan sebagainya. Sebagai contoh: Sebuah perusahaan ingin menjual beberapa produk memerlukan beberapa informasi seperti: deskripsi produk, alasan pembelian produk, benefit produk, shopping cart untuk pembelian e-commerce, metode pembayaran, dan sebagainya. Dalam setiap lingkup diperlukan kebutuhan (requirement) tertentu, misalnya: pada lingkup kategori produk, diperlukan spesifikasi produk, foto produk, warna produk, dan sebagainya (Garrett, 2011). Tahap bidang struktur (struktur plane) adalah tahap pembuatan struktur informasi agar komunikasi berjalan sesuai dengan urutan yang diharapkan.

Tahap ini dapat disebut juga sebagai tahap pembuatan arsitektur informasi. Hal yang perlu diperhatikan dalam pembentukan struktur informasi adalah harus mengacu pada kemudahan 
pelanggan dalam mengakses informasi. Untuk menggambarkan struktur informasi dapat disajikan dalam flowchart. Dalam tahap ini interaksi dengan pengguna juga harus ditentukan. Misalnya bagaimana pengguna berpindah dari informasi satu ke informasi lainnya dengan mudah tanpa menjadi bingung (Garrett, 2011). Tahap bidang rangka (skeleton plane) ibarat pembuatan draft layout dimana struktur informasi telah diaplikasikan ke dalam layout namun belum dalam tampilan visual akhir. Dalam dunia desain komunikasi visual tahap ini adalah pembuatan grid lay out dan penempatan teks di dalamnya. Ketepatan dalam meletakan informasi pada media komunikasi menjadi dasar mudah tidaknya hirarki informasi dapat disampaikan (Garrett, 2011). Tahap bidang permukaan (surface plane) diibaratkan polesan terakhir yang memberi tone and manner tampilan visual. Disini dipertimbangkan elemen dan prinsip desain seperti gerak, warna, harmoni, dan sebagainya. Model Garrett merupakan model linear dimana proses satu harus dimulai jika proses sebelumnya telah selesai (Garrett, 2011).

2. Model David Armano David Armano Seorang Executive Vice President Global Innovation \& Integration di Edelman Digital, sebuah agensi digital terkemuka mengemukakan sebuah model interactive experience. Jika model Garrett lebih mengaris bawahi struktur, interaksi, 
dan kegunaan (usability), model Armano menarik ke belakang beberapa langkah dalam mencari user insight (Wiryawan, 2011).

Armano membagi prosesnya menjadi 5 langkah yaitu uncover, define, ideate, build, dan desain.

a. Uncover adalah pencarian sesuatu yang mendasar dari motivasi dan kepentingan customer, business, brand, yang dihubungkan dengan pemahaman wawasan teknologi. Dalam mencari customer insight dapat digunakan berbagai perangkat riset seperti behaviour mapping, social trends analysis, dan sebagainya, untuk mencari model rasional dan emosional khalayak yang dituju.

b. Tahap define ini merupakan tahapan perumusan strategi pembentukan pengalaman khalayak. Tahap ini mirip dengan tahap strategy plane pada model Garrett. Tujuan dari tahap ini adalah memberikan inspirasi dan arah baik kepada internal team maupun klien.

c. Ideate merupakan tahap kolaborasi dan eksplorasi. Dalam dunia pendidikan kreatifitas, sering juga disebut proses emphatising yaitu proses memahami khalayak dengan memasuki dunia mereka dan berperan sebagai mereka. Kemudian dicari pendekatan yang paling tepat untuk khalayak sesuai tujuan komunikasi. 
d. Build adalah proses membuat Big Idea dan mencoba mewujudkannya lewat prototype. Prototype diuji dan diperbaiki lewat riset kepada khalayak.

e. Proses desain adalah proses finalisasi dan eksekusi dari prototype yang telah diuji. Semua fungsi dan interaksi dimaksimalkan di proses ini. 


\section{BAB V TEKNIK PENULISAN DIGITAL DAN \\ PENGELOLAAN HUBUNGAN PELANGGAN}

\section{A. Definisi Copywriting}

Banyak definisi apa yang dimaksud dengan copywriting. Salah satu yang paling gampang, copywriting adalah salah satu teknik seni penulisan dan tujuannya untuk mendapatkan respon dari pembacanya. Media dalam copywriting tidak hanya dalam bentuk tulisan saja, tetapi bisa menggunakan gambar atau dalam bentuk video.

Menurut Wikipedia, copywriting adalah tulisan yang dibuat oleh seorang writer tujuannya disebarkan untuk kepentingan komersil. Contoh copywriting banyak digunakan untuk iklan pada website, landing page, televisi, majalah, koran dan media lainnya.

Sekarang ini dengan perkembangan internet yang semakin maju, copywriting seolah menjadi salah satu hal wajib yang harus ada. Tetapi untuk bisa menjadi seorang copywriter tidaklah mudah, Anda harus tahu teknik copywriting yang bisa menarik konsumen. Salah satu teknik yang banyak digunakan oleh copywriter adalah AIDA (Attention, Interest, Desire dan Action).

\section{B. Peran Copywriting Itu Penting Dalam Bisnis}

Ada yang menyebutkan bahwa copywriting memiliki peran $80 \%$ dalam bisnis. Jika Anda melewatkan copywriting berarti Anda sudah membuang $80 \%$ biaya 
dan waktu yang sudah dikeluarkan. Ironisnya saat ini belum banyak para pelaku bisnis online yang menerapkan copywriting dengan baik dan benar. Mereka masih asal memberikan content dan materi iklan yang kurang menarik konsumen.

Pernahkah Anda melihat 2 produk sama persis, yang satu dijual dengan hanya mencatumkan informasi, desktipsi, fitur, manfaat, harga dan cara memesan. Setelah ditunggu lama tidak ada orang yang membeli produk Anda sama sekali, lalu apakah ada yang salah? Jawabnya tidak ada.

Produk kedua produknya sama persis, yang membedakan produk kedua memiliki pembeli yang rama dan atusias terhadap produk yang dijual. Apakah mereka menggunakan penglaris? Jawabnya tidak. Mereka menggunakan teknik copywriting yang mampu menyihir yang mampu membuat para konsumen bukan lagi ingin tetapi harus membeli produk yang Anda jual.

\section{Model Copywriting}

Contoh dalam pembuatan copywriting berikut ini menggunakan urutan AIDA (Attention, Interest, Desire dan Action). Saya mengambil contoh untuk penjualan obat herbal penurun berat badan dengan target pembeli wanita karir yang belum menikah.

1. Attention

Attention tujuan utamanya adalah untuk menarik perhatian dari pembaca yang menjadi calon konsumen kita. Ini contoh kalimat yang bisa Anda gunakan untuk copywriting: 
a. Ingin punya berat badan ideal dalam sebulan tanpa harus melakukan diet ketat?

b. Kembalikan tubuh indahmu saat sepeti masa muda dulu lagi

c. Kangen memiliki bentuk tubuh saat masih ABG dulu lagi?

d. Tidak punya waktu untuk berolahraga karena kesibukan kerja? Sekarang Anda bisa menurunkan berat badan tanpa harus repot olahraga yang menyita waktu.

2. Interest

Langkah selanjutnya setelah interest, buat mereka calon konsumen yang datang menjadi tertarik dengan produk obat herbal penurun berat badan yang Anda jual sehingga mereka mau melanjutkan membaca copywriting sampai akhir. Ingatkan dengan masalah berat badan yang mereka miliki agar lebih menarik. Tambahkan beberapa informasi, fakta, data statistik, alasan yang membuat calon konsumen semakin tertarik. Berikut contohnya:

a. Terbukti mampu menurunkan berat badan $10 \mathrm{~kg}$ dalam satu bulan

b. Menjadikan Anda lebih cantik sepeti saat muda dulu

c. Bisa terlihat 5 tahun lebih awet muda

d. Banyak para pria yang mendekat

e. Pekerjaan tetap jalan tidak terganggu

3. Desire 
Formula AIDA yang ketiga adalah desire, desire ini memiliki kemiripan dengan interest, bedanya lebih memainkan emosi dan logika konsumen. Biasanya dilakukan dengan menyebutkan manfaat yang akan didapatkan. Berikut contohnya:

a. Waktu Anda sangat berharga dari pagi sampai sore bekerja dikantor

b. Dengan kesibukan kerja yang padat, olahraga menjadi hal yang sulit dilakukan

c. Pekerjaan lancar badan bisa kurus

4. Action

Tahap terakhir dalam AIDA adalah Action atau mengambil tindakan. Tindakan bisa apa saja tergantung dari tujuan produk itu dijual. Contoh tindakan yang banyak dilakukan seperti pembelian, mendaftar, pembuatan akun, download, submit email dan lain sebagainya.

Tindakan biasanya dipicu dengan memberikan Call to Action (CTA) pada bagian akhir. Bentuk CTA bisa berupa tulisan, tombol, nomor telpon, alamat email dan harga. 


\section{BAB VI SEARCH ENGINE OPTIMIZATION}

Search Engine Optimization merupakan solusi untuk mengoptimalkan halaman website anda agar mendapatkan peringkat di halaman hasil pencarian Google Search Engine. Terdapat dua jenis SEO, yaitu SEO On Page dan Off Page. Pastikan untuk menerapkan semua indikator yang telah kami jelaskan, dan selalu ikuti perkembangan dari algoritma update setiap saat. Selain itu, buatlah konten yang tidak mengandung unsur plagiasi dan duplikasi dengan kompetitor anda.

\section{A. Pengertian SEO}

Search Engine Optimization atau SEO adalah sebuah bentuk apresiasi yang diberikan kepada halaman website yang masuk pada halaman pertama di mesin pencari Google. Jadi, definisi umum dari SEO adalah cara untuk mengoptimalkan situs web agar masuk pada peringkat teratas di hasil pencarian, khususnya pada organic research. Yang mana, pencarian organik tersebut dilakukan oleh user atau saat memasukkan kata kunci pencarian (keyword) pada browser dan search engine Google.

SEO sangat berfokus pada pencarian kata kunci secara organik dan berbeda dengan SEM yang berfokus pada media iklan yang disediakan oleh Google. Sehingga, jika anda membuat sebuah website, maka 
akan lebih baik untuk melakukan optimasi dengan SEO daripada menggunakan SEM, karena anda harus membutuhkan dana atau modal untuk melakukan promosi iklan di Google.

\section{B. Tipe Trafic SEO}

Setelah mengetahui pengertian SEO, selanjutnya masuk pada pembahasan mengenai beberapa jenis tipe trafik dari SEO. Untuk sekarang, terdapat tiga jenis trafik yang dapat digolongkan sesuai dengan fungsi dan kinerjanya masing - masing.

1. Quality Traffic

Tipe yang pertama adalah quality traffic atau lebih dikenal dengan trafik yang berkualitas. Untuk menentukan nilai kualitas trafik, dapat diukur dari seberapa besar nilai dari konversi yang dihasilkan dari data pengunjung yang masuk pada website anda.

Untuk website bisnis, semakin banyak pengunjung situs yang berganti menjadi pembeli, maka semakin baik pula kualitas trafik dari website anda. Pada umumnya, pengunjung akan melihat dan mencari tahu apa saja produk yang anda tawarkan. Sehingga, hal tersebut termasuk ke dalam trafik dengan menggunakan bantuan kata kunci transaksional.

2. Quantity of Traffic

Kuantitas dari sebuah trafik juga sangat diperhitungkan untuk meningkatkan performa 
sebuah website. Semakin banyak pengunjung yang masuk pada setiap halaman website anda, maka semakin besar nilai trafik yang dapat anda peroleh. Jadi, ketika anda mengembangkan situs web bisnis, maka anda perlu memperbanyak halaman dengan konten yang berkualitas. Dimana, anda dapat membuat kumpulan artikel dalam bentuk blog yang mengandung keyword yang bersifat informasional.

\section{Organic Traffic}

Dan tipe yang terakhir adalah trafik organik, dimana sangat disukai oleh pemilik website karena tidak membutuhkan biaya atau gratis. Dengan trafik organik, juga dapat mendatangkan jumlah pengunjung yang lebih banyak serta meningkatkan konversi.

Sebagai contoh, ketika seseorang mengetikkan kata kunci dalam mesin pencari di sebuah browser, dan selanjutnya user tersebut akan meng-klik link yang ditampilkan pada hasil pencarian. Nah, kunjungan link tersebut yang merupakan sebuah organic traffic.

\section{Cara Kerja dan Teknik SEO}

Setelah mengetahui beberapa jenis trafik, maka berikutnya masuk pada pembahasan mengenai apa saja cara kerja dan teknik SEO untuk dapat membantu mengoptimalkan halaman website di mesin pencari. 
Pertama, hal yang perlu anda perhatikan adalah untuk dapat masuk pada halaman pertama dan mendapatkan top position antara peringkat 1 hingga 3, tidak sesederhana yang anda bayangkan. Mesin pencari atau search engine sendiri memiliki tiga tugas utama untuk mencari permintaan atau request yang anda ketikkan.

1. Crawling

Proses yang pertama adalah mesin pencari akan melakukan crawling, dimana bertujuan untuk mengumpulkan informasi dari seluruh website, mulai dari halaman hingga link.

2. Indexing

Proses yang pertama adalah mesin pencari akan melakukan crawling, dimana bertujuan untuk mengumpulkan informasi dari seluruh website, mulai dari halaman hingga link.

3. Ranking

Dan tahap terakhir, search engine akan menampilkan hasil peringkat berdasarkan pencarian yang paling sesuai dengan konten yang relevan dengan keyword yang disasar.

Kemudian, algoritma Google juga selalu memastikan pengguna untuk mendapatkan informasi dan konten dari sumber yang relevan dan terpercaya. Google sendiri juga memiliki algoritma update yang setiap saat akan mengalami perubahan menyesuaikan dengan perkembangan zaman dan teknologi yang ada. 
Penyebutan algoritma tersebut menggunakan nama - nama khusus, diantaranya adalah Panda, yaitu algoritma yang berkaitan dengan aktivitas penyaringan (filter), penghargaan, pemberian penalti terhadap konten website. Kemudian Penguin adalah algoritma yang berfungsi untuk mencegah terjadinya spamdexing. Dan terakhir adalah Hummingbird, yaitu algoritma yang berfungsi untuk meningkatkan kualitas dari kedua algoritma tersebut.

Terkait dengan teknik SEO, anda perlu untuk belajar lebih dalam terkait dengan bahasa pemrograman dan aktivitas teknis. Terdapat beberapa metrik yang harus anda perhatikan dan optimalkan untuk meningkatkan performa dari halaman web.

Contohnya adalah melakukan audit pada core web vital, robot.txt, sitemap, breadcrumbs, page speed, dan lain sebagainya. Anda dapat mengecek informasi tersebut pada tools yang disediakan oleh Google, yaitu Google Search Console (GSC) dan Google Analytics (GA). Dan jangan lupa untuk selalu melakukan perbaikan dan optimasi pada SEO on page dan off page.

\section{Jenis SEO}

Setelah mengetahui beberapa informasi mengenai cara kerja dan teknik SEO, selanjutnya masuk pada pembahasan mengenai jenis - jenis dari Search Engine Optimization.

1. SEO on Page 
Jenis yang pertama adalah melakukan optimasi dengan SEO on page. Penerapannya dapat dilakukan dengan melakukan beberapa perbaikan dan perubahan pada konten dan halaman website anda. Terdapat beberapa hal yang perlu diperhatikan, diantaranya adalah sebagai berikut:

a. Melakukan keyword research (Riset kata kunci)

Sebelum membuat sebuah website, pastikan anda telah melakukan riset kata kunci yang berhubungan dengan bisnis anda. Tujuannya adalah supaya anda dapat mengetahui seberapa besar proyeksi trafik yang bisa anda peroleh sesuai dengan keyword yang relevan dengan bisnis anda.

Selain itu juga, perlu untuk mengecek keyword yang digunakan oleh kompetitor anda, supaya anda dapat membuat halaman dengan konten yang lebih baik dari kompetitor bisnis. Pastikan juga untuk membuat konten atau tampilan halaman situs yang menarik dan unik, agar saat Google melakukan crawling, website anda tidak dianggap sebagai spam atau mengandung unsur duplikasi atau plagiasi konten.

b. Perbaikan hal teknis

Untuk mempermudah pekerjaan dari web crawler pastikan anda untuk selalu melakukan audit mengenai masalah teknis dalam SEO on 
page. Perbaikan dari hal teknis, meliputi pengecekan sitemap, mengganti link yang rusak (broken link), menghindari kesalahan dalam proses redirect, hingga perbaikan URL yang rusak.

c. Optimasi halaman web

Langkah yang ketiga yaitu melakukan perbaikan, khususnya untuk bagian konten dari situs web anda. Optimasi tersebut meliputi penambahan meta title dan description, pembuatan heading yang baik, persebaran keyword density, penulisan alt image, struktur konten yang jelas, serta pembuatan konten yang relevan dengan keyword yang anda targetkan.

d. Menyesuaikan user experience

Dan yang terakhir adalah, penyesuaian dari setiap elemen, warna, teks, gambar, hingga tombol dari halaman website anda supaya pengunjung mendapatkan pengalaman yang baik. Disamping itu, anda juga harus memperhatikan kecepatan web, hingga pengembangan struktur konten yang sesuai dengan tema yang dibuat.

Semakin mudah user dalam mengakses situs anda, maka akan berbanding lurus dengan meningkatnya trafik pengunjung dan menambah nilai authority dari website anda.

\section{SEO off Page}


Jenis yang kedua adalah optimasi website dengan cara SEO off page. Untuk langkah ini biasanya berfungsi untuk membantu meningkatkan trafik website, apabila dalam perkembangannya optimasi on page dirasa masih belum cukup dan mampu untuk meningkatkan konversi trafik untuk bisnis anda.

a. Menambahkan Backlink

Backlink merupakan cara yang paling sering digunakan oleh pemilik website untuk dapat meningkatkan authority jika situs link anda ditempatkan atau berada pada pemilik website yang lain. Jadi, situs link yang anda miliki akan berada pada website lain dan biasanya menjadi bentuk rekomendasi terhadap situs anda.

b. Melakukan Promosi

Anda juga dapat melakukan promosi dengan cara mengunggah halaman website anda pada situs media sosial yang anda miliki. Tujuannya adalah untuk mendapatkan cakupan pengunjung yang lebih luas lagi. Untuk platform media sosial yang dapat anda sasar adalah Facebook, Twitter, dan Instagram.

Pada ketiga platform tersebut juga menyediakan promosi dalam bentuk iklan berbayar untuk mempromosikan produk bisnis anda. Semakin banyak relasi yang terbentuk 
dapat menambahkan jumlah trafik yang masuk pada situs yang anda buat.

\section{E. Indikator Utama SEO}

Terdapat setidaknya ada 8 indikator utama untuk mengoptimalkan halaman web dengan SEO. Berikut ini merupakan penjelasan terkait dengan kedelapan indikator tersebut.

1. Struktur URL

Indikator pertama yang harus diperhatikan adalah pembuatan struktur URL yang benar dan sesuai dengan topik yang dibahas. Selain itu, pastikan juga untuk membuat permalink atau slug yang mengandung main keyword dari halaman konten web anda.

2. Penggunaan SSL/TLS

Sejak tahun 2014, Google lebih memprioritaskan website yang menggunakan SSL/TLS. Dengan adanya SSL, dapat meningkatkan keamanan data pengguna karena telah dienkripsi ketika proses transfer data yang terjadi pada website.

Sertifikat SSL (Secure Socket Layer) sangatlah penting dalam mengoptimalkan website. Cara untuk mengetahui, apakah website anda mempunyai SSL/TLS atau tidak adalah dengan cara melihat URL anda. Jika masih menggunakan HTTP, maka website anda sudah dipastikan tidak memiliki SSL/TLS. Namun, apabila mempunyai 
bukti sertifikat, maka URL anda akan berawalan HTTPS.

3. Menentukan topic konten

Setelah melakukan beberapa persiapan diatas, selanjutnya adalah menentukan topik yang ingin anda kuasai. Untuk mendapatkan konten yang menarik, dengan trafik yang besar, kami menyarankan untuk melakukan keyword research untuk mendapatkan informasi secara lebih detail yang relevan dengan bisnis anda.

4. Menentukan Search Intent

Indikator berikutnya adalah dengan menentukan search intent terlebih dahulu. Search intent sendiri merupakan pembagian kata kunci berdasarkan tujuan bisnis yang hendak dicapai. Setidaknya, terdapat empat macam search intent, meliputi:

a. Informational, untuk kebutuhan dalam memberikan berbagai informasi topik secara luas.

b. Navigational, untuk mengarahkan kata kunci pada nama perusahaan / brand langsung.

c. Commercial Investigation, untuk kebutuhan yang bersifat komersial dan membandingkan dua produk.

d. Transactional, yaitu kata kunci yang digunakan untuk kebutuhan dan meningkatkan nilai konversi bisnis. 
5. Membuat Struktur Konten

Selanjutnya, membuat struktur konten yang baik dan sesuai dengan prinsip penulisan artikel yang baik. Pada umumnya akan menggunakan prinsip $5 \mathrm{~W}+1 \mathrm{H}$. Jangan lupa untuk membuat heading structure, menambahkan gambar, video atau infografis untuk menunjang konten yang anda buat.

6. Menambahkan Meta Tag

Indikator yang keenam adalah menambahkan meta title dan description. Hal ini sangatlah penting, untuk membantu Google dalam mengenali halaman website anda. Dalam pembuatannya, juga terdapat aturan penting, dimana tidak menuliskan meta title dan description terlalu banyak.

7. Menambahkan Backlink

Semakin banyak backlink yang anda dapatkan, maka Google akan menganggap website anda mempunyai kredibilitas yang tinggi. Pastikan backlink yang anda dapatkan berasal dari blog atau website yang berkualitas.

8. Mengoptimalkan Kecepatan Website

Untuk indikator yang terakhir, merupakan hal yang terpenting untuk dilakukan. Sejak tahun 2018, Google telah menetapkan bahwa kecepatan loading website, baik pada desktop maupun mobile termasuk dalam salah satu indikator SEO. Semakin cepat website anda, maka semakin anda mudah 
untuk mendapatkan ranking pada halaman pencarian di search engine.

\section{F. Manfaat Dari Adanya SEO}

Terdapat beberapa manfaat yang dapat anda peroleh dari adanya SEO. Berikut ini, merupakan beberapa penjelasan berkaitan dengan hal tersebut.

1. Meningkatkan Traffic Pengunjung

Dengan adanya SEO, maka manfaat yang dapat anda dapatkan adalah meningkatnya jumlah trafik pengunjung website secara organik. Anda tidak perlu mengeluarkan biaya untuk promosi iklan.

2. Meningkatkan Konversi Bisnis

Nilai konversi juga akan ikut meningkat dengan adanya SEO. Pastikan untuk menargetkan keyword transactional untuk mendapatkan pengunjung yang ingin membeli produk atau jasa anda.

3. Menjangkau User yang Lebih Luas

SEO juga dapat menjangkau user yang lebih luas. Cukup dengan membuat artikel blog, dengan menerapkan keyword yang bersifat informasional, serta melakukan optimasi baik dengan on page, maupun off page.

4. Mendapatkan Keuntungan Bisnis dalam Jangka Waktu yang Panjang

Dan manfaat yang terakhir adalah mendapatkan keuntungan (profit) dalam jangka waktu yang lebih lama. Pastikan juga untuk selalu melakukan optimasi terhadap website anda secara berkala dan 
melakukan riset kompetitor dan mengikuti perkembangan dari algoritma update Google. 


\section{A. Definisi Search Advertising}

Dalam pemasaran Internet, pencarian iklan adalah metode menempatkan iklan online di halaman web yang menampilkan hasil dari permintaan mesin pencari . Melalui layanan iklan mesin pencari yang sama, iklan juga dapat ditempatkan di halaman Web dengan konten lain yang diterbitkan.

Iklan pencarian ditargetkan untuk mencocokkan istilah pencarian utama (disebut kata kunci) dimasukkan di mesin telusur. Kemampuan penargetan ini telah berkontribusi pada daya tarik iklan penelusuran bagi pengiklan. Konsumen akan sering menggunakan mesin pencari untuk mengidentifikasi dan membandingkan opsi pembelian segera sebelum membuat keputusan pembelian. Peluang untuk menampilkan iklan yang disesuaikan dengan minat beli langsung kepada konsumen mendorong konsumen untuk mengeklik iklan penelusuran alih-alih hasil penelusuran gratis, yang seringkali kurang relevan. Untuk pengguna online, Iklan Pencarian Bersponsor menawarkan hasil pencarian yang sangat relevan yang didasarkan pada permintaan konsumen sendiri dan, oleh karena itu, dianggap kurang mengganggu daripada iklan banner atau iklan pop-up. Tambahan,Iklan Pencarian Bersponsor mengurangi biaya pencarian pengguna online dan meningkatkan aksesibilitas ke 
informasi berguna dalam jangka waktu yang terbatas. Akibatnya, Iklan Penelusuran Bersponsor telah menjadi elemen penting dalam penjelajahan pengguna online dan pengalaman pencarian informasi di Web. Iklan penelusuran adalah alternatif untukSEO dan SEM.

Iklan web sebelum tahun 1998 terdiri dari iklan spanduk yang umumnya diberi harga berdasarkan jumlah tayangan yang disampaikan (yaitu, harga BiayaPer-mili (CPM)). GoTo.com (berganti nama menjadi Overture pada 2001, dan diakuisisi oleh Yahoo! Pada 2003) menciptakan lelang pencarian bersponsor pertama, dan lelang pencarian bersponsor pertama Google menyusul pada 2002.

\section{B. Aktivitas Periklanan}

Aktivitas periklanan penelusuran dapat diukur dengan lima cara:

1. CPM: Biaya per seribu penonton adalah metode asli yang digunakan untuk menentukan harga iklan online. CPM tetap menjadi metode paling umum untuk menentukan harga iklan banner.

2. RKT: Rasio klik-tayang mengukur berapa kali iklan diklik sebagai persentase tampilan halaman Web tempat iklan itu muncul. Iklan spanduk memiliki RKPT yang umumnya 0,5 persen atau kurang. Sebagai perbandingan, iklan mesin telusur individual dapat memiliki RKT 10 persen, meskipun muncul di samping hasil penelusuran organik dan iklan penelusuran berbayar pesaing. ${ }^{[5]}$ 
3. BPA: Biaya per tindakan menghitung biaya untuk menyelesaikan aktivitas tertentu seperti menarik pelanggan baru atau melakukan penjualan. Jaringan afiliasi beroperasi dengan basis CPA. Sistem CPA berfungsi paling efektif saat siklus penjualan pendek dan mudah dilacak. Siklus penjualan yang lebih lama bergantung pada keterpaparan ke beberapa jenis iklan untuk menciptakan kesadaran merek dan minat beli sebelum penjualan dilakukan. Siklus penjualan yang lebih lama dan penjualan yang membutuhkan banyak kontak pelanggan bisa jadi sulit dilacak, yang menyebabkan keengganan penerbit untuk berpartisipasi dalam program CPA di luar perolehan prospek awal.

4. BPK: Biaya per klik melacak biaya berinteraksi dengan klien atau calon klien. Dalam pemasaran tradisional, BPK dipandang sebagai proses satu arah untuk menjangkau khalayak sasaran melalui sarana seperti surat langsung, iklan radio dan iklan televisi. Iklan penelusuran memberikan peluang untuk kontak dua arah melalui obrolan berbasis web, panggilan berbasis Internet, permintaan panggilan balik, atau pendaftaran milis. Ada beberapa pedoman untuk menetapkan prosedur penghitungan minimum yang dapat diterima untuk klik. Setiap klik memiliki siklus hidup yang dikenal sebagai siklus rujukan klik. Ini terdiri dari empat tahap: Klik yang dimulai, Klik terukur, Klik yang diterima, dan Klik terselesaikan. 
5. TM: Total menit adalah metrik yang digunakan oleh Nielsen / NetRatings untuk mengukur total waktu yang dihabiskan di halaman Web daripada jumlah tampilan halaman Web. Pada 10 Juli 2007, Nielsen mengumumkan bahwa mereka akan mengandalkan TM sebagai metrik utama mereka untuk mengukur popularitas halaman Web, karena perubahan cara halaman Web menyediakan konten melalui streaming audio dan video dan dengan menyegarkan halaman yang sama tanpa memuatnya kembali. Pertanyaan metodologis mengenai penggunaan total menit untuk iklan pencarian termasuk bagaimana menghitung pengguna Internet yang membiarkan beberapa jendela browser terbuka secara bersamaan, atau yang membiarkan satu jendela terbuka tanpa pengawasan untuk jangka waktu yang lama. Pertanyaan lain melibatkan pelacakan total menit pada halaman HTML yang tidak memiliki kewarganegaraan dan oleh karena itu tidak menghasilkan data sisi server selama halaman tersebut dilihat.

Iklan mesin pencari dibeli berdasarkan kata kunci. Pembeli iklan terlibat dalam menjalankan tindakan untuk kata kunci, dengan kata kunci populer berharga beberapa dolar per klik.

Mesin pencari menggunakan algoritma untuk menentukan posisi iklan sesuai dengan rasio kliktayang. Iklan dengan rasio klik-tayang yang buruk 
dapat didorong ke bagian bawah halaman pertama hasil pencarian atau ke halaman berikutnya. Meskipun pengiklan hanya membayar untuk klik-tayang, algoritme yang menetapkan posisi iklan berdasarkan popularitas iklan memberikan insentif untuk mengoptimalkan pemilihan kata kunci dan tindakan pengendalian biaya lainnya.

\section{Efisiensi Advertising}

Tanpa tindakan pengendalian biaya, pembeli iklan mungkin menghabiskan dua puluh lima sampai lima puluh persen dari anggaran iklan mereka secara tidak efektif.

Tindakan pengendalian biaya dapat mencakup:

1. Kampanye dapat dimulai dengan lambat, untuk menguji keefektifan kata kunci dan teks iklan. Diperlukan waktu tiga bulan pengujian sebelum kampanye siap ditingkatkan. Kampanye awal dapat menghabiskan US \$20-\$40 per hari, sedangkan kampanye besar dapat melebihi US \$ 1000 per hari. Beberapa kampanye dapat dijalankan berdampingan.

2. Kata kunci negatif dapat digunakan untuk mengecualikan permintaan pencarian yang tidak berhubungan dengan iklan yang akan ditampilkan. Penjual jendela pengganti untuk gedung, misalnya, dapat menggunakan kata kunci negatif 'perangkat lunak' atau 'program' untuk mencegah iklan mereka muncul sebagai tanggapan atas permintaan 
pencarian untuk informasi tentang perangkat lunak Microsoft Windows.

3. Urutan kata dalam kombinasi kata kunci dapat berpengaruh pada rasio klik-tayang. Urutan kata dalam membeli iklan sesuai kata kunci dapat dikontrol melalui penggunaan tanda petik. Melanjutkan contoh di atas dari perspektif penjual jendela pengganti, kata kunci "jendela pengganti" mungkin memiliki rasio klik-tayang yang lebih tinggi daripada "penggantian jendela" atau untuk kombinasi kata kunci terkait di mana sintaksis tidak ditentukan dan yang dapat dikaitkan dengan Microsoft Windows perangkat lunak daripada jendela untuk gedung.

4. Pencarian luas berarti bahwa iklan ditayangkan sebagai tanggapan atas permintaan pencarian yang berisi kata kunci, terlepas dari kata lain yang mungkin telah digunakan dalam permintaan pencarian. Menghilangkan pencarian luas dapat membantu jika ada banyak sekali kata kunci potensial atau ketika pengiklan berusaha untuk meminimalkan pengeluaran iklan. Perusahaan jendela pengganti yang berlokasi di Trenton, New Jersey dapat menghilangkan penelusuran luas yang mendukung kata kunci khusus lokasi seperti "jendela pengganti Trenton" dan lokasi lain dalam area pasar mereka. Setiap mesin pencari memiliki prosedurnya sendiri untuk mengontrol opsi pencarian yang luas untuk setiap kata kunci. 
5. Butuh waktu untuk mengidentifikasi dan memilih kata kunci potensial. Daripada menawar pada sejumlah kecil kata kunci populer, pengiklan dapat memperluas daftar kata kunci mereka menjadi lebih dari 200 dan berusaha memasukkan kata kunci yang tidak digunakan pesaing mereka. Kata kunci yang kurang dicari lebih murah. Untuk mengidentifikasi opsi kata kunci, masukkan 'alat kata kunci' ke dalam mesin pencari. Penggunaan merek dagang pesaing sebagai kata kunci telah menjadi kontroversi di AS dan di seluruh dunia.

6. Penggunaan merek dagang sendiri sebagai kata kunci juga telah menjadi kontroversi, tetapi penelitian menunjukkan bahwa ada banyak keuntungan dalam menggunakan metode itu tidak hanya untuk mendominasi halaman hasil pencarian dengan SEO dan PPC dan mencegah pesaing memanfaatkannya, tetapi juga untuk meningkatkan jumlah klik yang diperoleh merek; klik gabungan dari SEO dan PPC akan melebihi klik SEO bahkan jika SEO merek memiliki posisi pertama untuk kata kunci mereknya.

7. Kampanye iklan penelusuran dapat memberikan hasil langsung — tetapi sering kali membutuhkan perhatian segera. Iklan yang berkinerja buruk harus ditarik, daftar kata kunci disesuaikan, dan jumlah tawaran diubah untuk mencegah pembelanjaan berlebih. 
8. Lakukan riset pasar dengan layanan analisis pencarian untuk mengidentifikasi tren dan peluang pasar. Layanan ini sering kali mengungkapkan kata kunci apa yang menguntungkan untuk situs web lain di pasar sasaran Anda. Selain itu, mereka menampilkan kata kunci musiman dan muncul yang memungkinkan Anda merencanakan kampanye pemasaran yang lebih tepat waktu.

\section{Jenis Iklan Pencarian}

Platform paling populer untuk iklan pencarian adalah Google AdWords, karena Google adalah mesin pencari paling populer dengan margin yang besar, meskipun pengiklan cerdas juga menggunakan Iklan Bing (yang memberi mereka jangkauan tambahan dengan biaya lebih rendah).

AdWords dan jaringan periklanan penelusuran lainnya beroperasi pada sistem seperti lelang, tempat bisnis mengajukan tawaran untuk muncul di hasil penelusuran tertentu. Kapan dan di mana iklan Anda muncul, serta berapa banyak Anda membayar per klik, ditentukan oleh beberapa faktor, termasuk tawaran Anda serta Angka Mutu, ukuran relevansi iklan Anda dengan kata kunci yang Anda tawar.

Sistem Skor Kualitas penting karena mendorong pengiklan untuk membuat kampanye iklan berkualitas tinggi yang melayani pengguna mesin pencari dengan baik. Jika Anda mencoba untuk "mengirim spam" ke hasil penelusuran dengan iklan yang tidak relevan dan 
berkualitas rendah, Anda akan kesulitan membuat AdWords bekerja untuk Anda.

Selain iklan penelusuran biasa, AdWords menawarkan cara untuk menempatkan iklan Google di properti Google lainnya, seperti:

\section{Gmail}

2. Youtube

3. Jaringan Display Google

Jika dilakukan dengan benar, iklan mesin telusur adalah cara yang sangat efektif untuk menghasilkan bisnis baru dan mendorong penjualan online. Namun, penting untuk berhati-hati saat membangun dan mengelola kampanye penelusuran Anda. Kesalahan yang tampaknya kecil dapat menghabiskan uang Anda dan memotong ROI Anda. Struktur akun yang logis, Penting untuk mengatur akun iklan penelusuran Anda dengan cara yang logis sehingga Anda dapat mengoptimalkan berbagai jenis iklan dan kumpulan iklan secara terpisah. Untuk bantuan dengan langkah penting ini, lihat panduan lengkap kami untuk struktur akun AdWords.

\section{E. Iklan Online/Online Advertising}

Iklan Online adalah upaya pemasaran online dengan menampilkan sebuah situs web pada hasil pencarian search engine dengan cara berbayar. Iklan online juga dapat digambarkan sebagai kegiatan 
memasang iklan untuk menawarkan produk atau jasa lewat dunia maya, yang tujuannya tidak lain adalah untuk meraih keuntungan dari kegiatan penjualan.

\section{F. Jenis Online Advertising}

1. Iklan spanduk web

Spanduk web atau iklan spanduk biasanya adalah iklan grafis yang ditampilkan dalam halaman web. Banyak iklan spanduk dikirim oleh server iklan pusat .

Iklan spanduk dapat menggunakan multimedia untuk memasukkan video, audio, animasi, tombol, formulir, atau elemen interaktif lainnya menggunakan applet Java , HTML5, Adobe Flash , dan program lainnya.

2. Bingkai iklan (spanduk tradisional)

Iklan bingkai adalah bentuk pertama dari spanduk web. Penggunaan sehari-hari "iklan spanduk" sering mengacu pada iklan bingkai tradisional. Penerbit situs web menggabungkan iklan bingkai dengan menyisihkan ruang tertentu di halaman web. The Interactive Advertising Bureau 's Unit Iklan Pedoman mengusulkan standar dimensi pixel untuk unit iklan.

3. Pop-up / pop-under

Iklan pop-up ditampilkan di jendela browser web baru yang terbuka di atas jendela browser awal pengunjung situs web. Sebuah iklan pop-under membuka jendela browser baru di bawah jendela 
browser awal pengunjung situs web. Iklan popunder dan teknologi serupa sekarang dilarang oleh otoritas online seperti Google, yang menyatakan bahwa mereka "tidak membenarkan praktik ini".

4. Iklan mengambang

Iklan mengambang, atau iklan hamparan, adalah jenis iklan multimedia yang muncul tumpang tindih di atas konten situs web yang diminta. Iklan mengambang dapat menghilang atau menjadi tidak terlalu mencolok setelah jangka waktu yang telah ditentukan sebelumnya.

5. Memperluas iklan

Iklan yang diperluas adalah iklan bingkai multimedia yang mengubah dimensi pada kondisi yang ditentukan sebelumnya, seperti jumlah waktu yang telah ditentukan sebelumnya yang dihabiskan pengunjung di laman web, klik pengguna pada iklan, atau gerakan mouse pengguna di atas iklan. Memperluas iklan memungkinkan pengiklan memasukkan lebih banyak informasi ke dalam ruang iklan yang dibatasi.

6. Spanduk trik

Spanduk trik adalah iklan spanduk yang salinan iklannya meniru beberapa elemen layar yang biasa ditemui pengguna, seperti pesan sistem operasi atau pesan aplikasi populer, untuk mendorong klik iklan. Spanduk tipuan biasanya tidak menyebutkan pengiklan di awal iklan, dan karenanya merupakan 
bentuk umpan-dan-peralihan. Spanduk tipuan biasanya menarik rasio klik-tayang yang lebih tinggi dari rata-rata , tetapi pengguna yang tertipu dapat membenci pengiklan karena menipu mereka.

7. Iklan Umpan Berita

"Iklan Umpan Berita", juga disebut "Cerita Bersponsor", "Pos yang Didorong", biasanya ada di platform media sosial yang menawarkan aliran pembaruan informasi yang stabil ("umpan berita" ${ }^{[42]}$ ) dalam format yang diatur (yaitu dalam ukuran kecil yang serupa kotak dengan gaya seragam). Iklan tersebut terkait dengan berita non-promosi yang dibaca pengguna. Iklan tersebut dapat berupa konten apa pun, seperti mempromosikan situs web, halaman penggemar, aplikasi, atau produk. Beberapa contohnya adalah: "Berita Sponsor" Facebook, ${ }^{[43]}$ "Pembaruan Sponsor" LinkedIn, ${ }^{[44]}$ dan "Tweet Promosi" Twitter. ${ }^{[45]}$

\section{G. Macam-Macam Online Advertising}

Ada beberapa jenis online marketing, diantaranya adalah :

1. Direct Advertising: di mana pemasang iklan dan pemilik media berhubungan langsung dan menandatangani kontrak untuk menampilkan iklan atau inisiatif promosi lainnya.

2. Self-service Advertising: Pendekatan iklan baru di mana materi iklan, penempatan iklan, tampilan serta teks dikerjakan sendiri oleh pemasang iklan 
melalui metode proses yang dilakukan sendiri di Online. Contoh: Blogads dan Google AdWords.

3. Ad Networks: Sebuah jaringan (network) iklan yang menghubungkan dan memediasi antara pemasang iklan dengan pemilik situs web. Jaringan iklan seperti ini biasanya menargetkan kampanyekampanye yang tidak mempunyai target audience khusus, tetapi mengincar sebesar mungkin orang yang melihat iklan dengan biaya sekecil mungkin. Contoh: ValueClickMedia dan Tribal Fusion.

4. Contextual Advertising: Iklan yang ditargetkan pada content. Iklan tidak ditampilkan secara random, tetapi telah dipilih oleh sistem secara otomatis sesuai dengan content yang relevan dengan iklan tersebut. Contoh: Google AdSense dan Yahoo Publisher Network.

5. Twitter Advertising: Iklan yang berfungsi sebagai tweet dari pemasang iklan, yaitu iklan berbasis keyword yang pendek, yang didistribusikan kepada user yang membaca content yang sesuai dengan keyword yang dipilih. Contoh: Magpie dan Twittad.

6. In-Text Advertising: Sistem in-text advertising secara otomatis menghubungkan kata-kata tertentu di dalam website dengan content iklan yang berhubungan. Contoh: Kontera dan Vibrant inText Ad.

7. Ad Network Optimization: Jasa optimasi iklan ini mengevaluasi dan memilih iklan yang membayar 
terbanyak untuk ditampilkan dalam halaman web dengan mengevaluasi semua pilihan serta ukuran iklan yang paling baik, dan karakteristik visualnya. Contoh: PubMatic dan YieldBuild.

8. Rep Ad Agencies: agen periklanan yang mewakili blog-blog serta situs web tertentu dan memediasi penjualan mereka untuk kampanye-kampanye besar yang dilakukan brand-brend besar ataupun agensi iklan besar. Contoh: Federated Media dan Tribal Fusion.

9. Social Advertising: Iklan untuk social media. Tidak seperti iklan tradisional, format iklan ini memanfaatkan dinamika pengaruh sosial seperti pengaruh peer group, word of mouth, viral marketing dan rekomendasi langsung dari teman ke teman. Contoh: VideoEgg dan Meebo.

10. Video Advertising: Bentuk iklan yang ditargetkan pada content video. Berbagai format tersedia, termasuk iklan dinamis yang bisa tampil sebelum, setelah, ataupun selama tayangnya content video tertentu. Contoh: Voxant dan AdSense for Video.

11. RSS Advertising: Iklan ini ditampilkan di dalam RSS Feed, yang bisa disesuaikan dengan konteks content RSS feed tersebut atau secara manual ditargetkan pada kebutuhan promosi tertentu. Contoh: Pheedo dan Feedvertising.

12. Sponsorship: adalah bentuk bantuan dana atau bisa juga dalam bentuk produk/layanan sebagai ganti 
promosi terhadap suatu brand. Sponsorship online adalah strategi alternatif yang banyak digunakan dan dianggap lebih efektif daripada pemasangan iklan online berbentuk banner. 
IBgN 978-623-6031-38-9 (PDF)

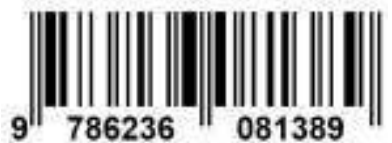

